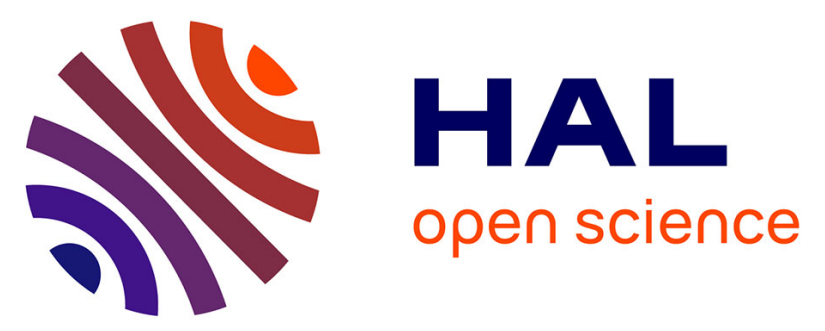

\title{
In situ assessment of phyto and zooavailability of trace elements: A complementary approach to chemical extraction procedures
}

Benjamin Pauget, Olivier Faure, Cyrille Conord, Nadia Crini, Annette De Vaufleury

\section{To cite this version:}

Benjamin Pauget, Olivier Faure, Cyrille Conord, Nadia Crini, Annette De Vaufleury. In situ assessment of phyto and zooavailability of trace elements: A complementary approach to chemical extraction procedures. Science of the Total Environment, 2015, 521-522, pp.400-410. 10.1016/j.scitotenv.2015.03.075 . hal-01242771

\section{HAL Id: hal-01242771 \\ https://hal.science/hal-01242771}

Submitted on 18 Jan 2016

HAL is a multi-disciplinary open access archive for the deposit and dissemination of scientific research documents, whether they are published or not. The documents may come from teaching and research institutions in France or abroad, or from public or private research centers.
L'archive ouverte pluridisciplinaire HAL, est destinée au dépôt et à la diffusion de documents scientifiques de niveau recherche, publiés ou non, émanant des établissements d'enseignement et de recherche français ou étrangers, des laboratoires publics ou privés. 


\section{In situ assessment of phyto and zooavailability of}

$5 *$ Corresponding Author

6 Benjamin Pauget

7 Department Chrono-environnement

8 UMR UFC/CNRS 6249 USC INRA

9 University of Franche-Comté

$10 \quad 16$ route de Gray

11 F-25030 Besançon Cedex

12 France

13 Tel.: +33(0) 381666352

14 Fax: +33(0) 381666797

E-mail: benjamin.pauget@univ-fcomte.fr

${ }^{1}$ Department of Chrono-Environment, University of Franche-Comté, UMR UFC/CNRS 6249

USC/INRA, 16 route de Gray, F-25030 Besançon Cedex, France.

${ }^{2}$ University of Lyon, UMR CNRS 5600 EVS-EMSE-Géosciences et Environnement Department,

ENSM-SE Mines Saint-Etienne, 158 cours Fauriel, F-42023 St-Etienne Cedex 2 
Key words: trace element, bioavailability, risk assessment, coupling bioindicators, soil parameters, contamination sources

\section{Abstract}

For an accurate risk assessment of sites contaminated by trace elements (TE), measurements of bioavailability must be performed. This is routinely achieved using the standardized $0.01 \mathrm{M} \mathrm{CaCl}_{2}$ method. However, the suitability of chemical extractions as proxies of bioavailability is questionable. We analyzed the correlations between chemically estimated TE bioavailability and TE actually accumulated by coupling plant and snails bioindicators. Results showed a better correlation between plant TE contents and $\mathrm{CaCl}_{2}$ fraction while total soil concentration better explained snail TE contents. However in both cases chemical measures were not suitable to predict TE accumulation and bioavailability. Considering the soil properties only improve the estimation of $\mathrm{Cr}, \mathrm{Ni}$ and $\mathrm{Pb}$ accumulation by plants while for snails, TE contents in viscera were dependent both on soil and plant contents and soil properties. It highlights the complementarities of biomonitoring methods to assess bioavailability. This dual approach allows a "physiologically defined" evaluation of bioavailability.

\section{Introduction}

Since a few decades, soil degradation (e.g., erosion, loss of organic matter, sealing, pollution, ...) is an increasing problem worldwide. Contamination by trace elements (TE) is considered as one of the main threats (Jeffery et al., 2010) because of human health issues (Qingdong et al., 2007 and Science Communication Unit, 2013), and also as they may cause severe ecological disturbances to both organisms and their habitats (Moriarty, 1999). For these reasons, various protective thresholds for total contents in soils have been proposed for different TE (Carlon, 2007). However it is largely acknowledge today that the toxicity of TE rather depends on their bioavailability than on their total contents in soils (Van Gestel et al., 2009). Consequently, protective thresholds based on total TE contents in soils are only coarse indications of the potential hazard, and should be completed by methods allowing to assess TE's bioavailability (ISO, 17402, 2008). 
However, although the term "bioavailability" can be easily understood as how much of a coowever, although the term "bioavailability" can be easily understood as how much of a contaminant is available for living organisms, the underlying concept is much more complex and a great number of definitions, and assessment methods, have been proposed so far (Harmsen, 2007, Naidu et al., 2008 and Semple et al., 2004). In an effort to offer a clear working definition of this concept, Semple et al. (2004) proposed to distinguish the part of the contaminant which is "bioaccessible" (i.e., "which is available to cross an organism's cellular membrane from the environment, if the organism has access to the chemical"), from that which is actually "bioavailable" (i.e., "which is freely available to cross an organism's cellular membrane from the medium the organism inhabits at a given time"). However this distinction has not been retained in the definition adopted in ISO 17402 ( ISO, 17402, 2008) which simply states that "bioavailability is the degree to which chemicals present in the soil may be absorbed or metabolized by human or ecological receptors or are available for interaction with biological systems". Whatever the terms and definitions considered, there is however a consensus today to regard bioavailability as a multi-level concept involving three distinct notions: the environmental availability, the environmental bioavailability and the toxicological bioavailability ( Gimbert et al., 2006, ISO 17402, 2008, Lanno et al., 2004 and Peijnenburg et al., 1997).

The environmental availability depends on multiple physico-chemical processes governing metal partition between the solid and liquid phases of the soil. Environmental availability is generally assessed as the so-called "available" or "easily exchangeable" TE fractions, using more or less weak chemical extractants, such as neutral salt solutions at low concentration or diluted weak acids. Because these chemical extraction methods are easy to use, reproducible and based on an easily understandable concept (the more the TE are easy to extract, the more they can interfere with living organisms), they are routinely used for risk assessment of contaminated sites. However numerous studies (Meers et al., 2007, Pauget et al., 2012, Peakall and Burger, 2003 and Van Gestel, 2008) have shown that the level of "available" elements, as determined by chemical extraction methods, is often a poor proxy of the fraction of TE that actually interacts with living organisms. By contrast, the environmental 
bioavailability refers to the fraction of contaminant that is actually taken up by biological receptors. It depends on complex species-specific physiological processes, controlling desorption of contaminants from the solid matrix and their assimilation (absorption and excretion) by the organism. To assess the environmental bioavailability of TE in soils, the use of accumulation bioindicators is obviously highly relevant (Peakall and Burger, 2003). Indeed, during the last two decades, plants (Le Guédard et al., 2012, Remon et al., 2013 and Vergé et al., 2002) or soil organisms, such as snails or earthworms (Dallinger and Berger, 1992, Gimbert et al., 2008a, Pauget et al., 2013, Rabitsch, 1996 and Scheifler et al., 2003), have been proposed as accumulation bioindicators. However, the transfer of TE and their accumulation by living organisms and in food webs depends both on the species, its trophic level and exposure pathways. It is thus questionable to use a single species or to consider a single trophic level for assessing bioavailability, as this may lead to misinterpretations.

In this work we hypothesized that considering different organisms, representative of different trophic levels (primary producers and primary consumers), could be a relevant approach to get information on the environmental bioavailability of TE in soils. Transfer to primary producers was estimated by analyzing TE content in composite plant samples, as recently proposed by Remon et al. (2013). This passive biomonitoring approach informs on the phytoavailability of TE for a plant community, considered as a whole. Transfer to primary consumers was assessed by active biomonitoring with garden snails, informing on the zooavailability of TE (Fritsch et al., 2011 and Gimbert et al., 2008a). We also assumed that the transfer of TE from soil to organisms at various spatial scales, could be partly conditioned by their environmental availability or/and by the soil properties. To address these issues, we performed an extensive study on 25 experimental plots (7 geographical sites) exemplifying different land use and contamination levels. We analyzed (i) the correlations between environmental availability and environmental bioavailability, as determined by chemical and biological methods, (ii) the influence of soil properties on TE accumulation by snails and plants and (iii) the relationship between TE concentrations in plants and TE accumulation by snails. 


\section{Materials and Methods}

\subsection{Selected sites and studied soils}

Seven sites (hereafter named Andra, Auzon, GISFI, Metaleurop, RENECOFOR, SHSE and Yvetot, S1) were selected throughout France (Fig. 1), among those studied in the French national research program "Bioindicators 2"; http://ecobiosoil.univ-rennes1.fr/ADEME-Bioindicateur. Each site was subdivided into two to six $100 \mathrm{~m}^{2}(10 \mathrm{~m}$ x $10 \mathrm{~m})$ experimental plots, according to the local typology and/or land use. The Auzon (6 plots), Metaleurop (4 plots), SHSE ( 3 plots) and GISFI (2 plots) sites were industrial landfills or peri-industrial woodlands and grasslands more or less impacted by industrial activities; the RENECOFOR site (4 plots) belonged to a network of French forests (http://www.onf.fr/renecofor); the Yvetot site (4 plots) was a cultivated grassland (Plassart et al., 2008) and the Andra site presented two plots, one in a forest and one in a grassland. All these sites and experimental plots have been previously described and located in Pérès et al. (2011) and in Pauget et al. (2013).

Samples of each plot were taken on a grid $(10 \mathrm{~m} \times 10 \mathrm{~m})$ subdivided into 4 sampling-zones $(5 \mathrm{~m} \times 5$ m). In each $25 \mathrm{~m}^{2}$ sampling zone, 12 randomized soil samples were taken $(0-15 \mathrm{~cm}$ depth after removal of the humus) and pooled to characterize soil physico-chemical parameters.

Soils from the 25 plots studied were analyzed for their pedological characteristics, as well as for their total and "available" TE contents. All analyses were performed by the Laboratory for Soil Analyses of the National Institute for Agronomic Research (INRA Arras, France), which benefits from the COFRAC (French Accreditation Committee) accreditation n¹-1380 (available at www.cofrac.fr) for its analytical insurance in soil metal(loid) measurements. Briefly, total metals $(\mathrm{Cd}, \mathrm{Cr}, \mathrm{Cu}, \mathrm{Ni}, \mathrm{Pb}$ and $\mathrm{Zn}$ ) in soil samples (routinely $250 \mathrm{mg}$ dry soil, ground at $<250 \mu \mathrm{m}$ ) were extracted using hydrofluoric (HF) and perchloric $\left(\mathrm{HClO}_{4}\right)$ acids, according to the NF X 31-147 procedure (AFNOR, 1996). For the determination of total As, soil samples were extracted with a mixture of sulfuric acid $\left(\mathrm{H}_{2} \mathrm{SO}_{4}\right) /$ nitric acid $\left(\mathrm{HNO}_{3}\right)(2 / 1, \mathrm{~V} / \mathrm{V})$ in the presence of vanadium pentoxide $\left(\mathrm{V}_{2} \mathrm{O}_{5}\right)$ at $100{ }^{\circ} \mathrm{C}$ for 3 
123 h. For the determination of "available" metal(loids), extractions were performed with $0.01 \mathrm{M}$ calcium

124 chloride $\left(\mathrm{CaCl}_{2}\right)$, according to the NEN 5704 procedure (NEN 5704, 1996). Metal concentrations in 125 the various extracts were measured using inductively coupled plasma atomic emission spectrometry 126 (ICP-OES). Selected pedological characteristics of the 25 plots studied and their total and $\mathrm{CaCl}_{2}$ 127 extractable TE contents are given in Supplementary Material S2 and S3.

\subsubsection{Plants}

To get a general insight into TE transfer toward plants, and to avoid species-specific responses, metal analyses were performed at a plant community level, i.e., using composite plant samples (Remon et al., 2013). The basic assumption of this approach is that TE concentrations in leaves of an ensemble of species colonizing a site, is a relevant indicator of TE phytoavailability in its whole.

Composite plant samples were prepared by collecting green leaves (during the months of June to August) from the most abundant species identified at each site, i.e., those species which were representative of the plant community in place. Ten to $15 \mathrm{~g}$ fresh weight (FW) of leaves was taken from four to five different species collected in the same area (approx. $5 \mathrm{~m}^{2}$ ) This elementary sampling was repeated five times in each plot (at each of the corners and in the center), with different species for each replica, when possible.

140 For each elementary sampling, specimens of each species were washed thoroughly with tap water and rinsed with distilled water. They were then dried at $40{ }^{\circ} \mathrm{C}$ to constant weight and individually ground up to pass through a 2-mm sieve. A composite sample ("pool”) was then prepared by mixing the same quantity (routinely $100 \mathrm{mg} \mathrm{DW}$ ) of each species constituting the pool. Five pools of plants were prepared in this way, for each plot studied.

146 Garden snails (Cantareus aspersus), were obtained from our laboratory breeding. They were fed 147 with commercial snail meal (Helixal®, Antigny Nutrition S.A., France) and reared under controlled 
conditions until the age of 7-9 weeks, as described by Gomot-de Vaufleury (Gomot-de Vaufleury, 2000). To avoid strong modification of mass during the exposure time that could lead to misinterpretation of internal concentration variations (Gimbert et al., 2008b), only sub-adults weighing $5.0 \pm 0.6 \mathrm{~g}(\mathrm{n}=1230)$ were used. At the beginning of the exposure, TE concentrations in the viscera were $0.33 \pm 0.11 \mathrm{~kg}^{-1}$ for As DW, $0.73 \pm 0.10 \mathrm{mg} \mathrm{kg}^{-1} \mathrm{Cd} \mathrm{DW}, 2.19 \pm 0.48 \mathrm{mg} \mathrm{kg}^{-1} \mathrm{Cr}$ DW, $139 \pm$ $40.1 \mathrm{mg} \mathrm{kg}^{-1} \mathrm{Cu}$ DW, $0.59 \pm 0.26 \mathrm{mg} \mathrm{kg}^{-1} \mathrm{~Pb} \mathrm{DW}$, and $881 \pm 182 \mathrm{mg} \mathrm{kg}^{-1} \mathrm{Zn} \mathrm{DW}$ (mean $\pm \mathrm{SD}, \mathrm{n}=$ $10)$.

For in situ exposure, snails were caged in microcosms $(25 \times 25 \mathrm{~cm}$ stainless steel cylinders $)$, during a 28-days period (during the months of June to August), as described by Fritsch et al. (2011). They were exposed to the soil and vegetation of each plot, under natural climatic conditions, from June to August, in 2009 (for Metaleurop, GISFI, F08 and F57), 2010 (for Auzon, SHSE, Yvetot, F63 and F76) and 2011 (for ANDRA). Fifteen snails were placed in each microcosm. On forest and grassland sites, one microcosm per plot was used and 6 individuals were sampled for TE analysis after 28 days. On sites contaminated by industrial activities, 3 microcosms per plot were used to account for the heterogeneity in soil contamination, and two snails per microcosm (= 6 snails) were sampled for TE analysis after 28 days.

\subsubsection{Plants}

Ground composite samples ("pools") were dried overnight at $40{ }^{\circ} \mathrm{C}$, before processing. Samples were then weighted (500 mg DW) into clean, dry PTFE (Teflon $\left.{ }^{\circledR}\right)$ screw cap digestion tubes, and $4 \mathrm{ml}$ concentrated nitric acid $\left(65 \% \mathrm{HNO}_{3}\right.$, analytical grade) were added. Open tubes were heated up to 50 ${ }^{\circ} \mathrm{C}$ for $1 \mathrm{~h}$, and kept overnight at room temperature. Three ml hydrogen peroxide $\left(36.5 \% \mathrm{H}_{2} \mathrm{O}_{2}\right.$, analytical grade) were then added and tubes were stand for $30 \mathrm{~min}$ at room temperature; they were then heated to $70{ }^{\circ} \mathrm{C}$ and allowed to evaporate until about $1 \mathrm{ml}$. A final aquae-regia digestion was then performed, by adding $2 \mathrm{ml}$ concentrated $\mathrm{HNO}_{3}$ and $4 \mathrm{ml}$ concentrated hydrogen chloride $(37 \% \mathrm{HCl}$, 
analytical grade); the tubes were hermetically closed and heated up to $150{ }^{\circ} \mathrm{C}$ for $2 \mathrm{~h}$. Samples were then cooled, tubes were opened, and kept at $70{ }^{\circ} \mathrm{C}$ until complete evaporation. Dry samples were finally solubilized in $10 \mathrm{ml} \mathrm{HCl}(2 \mathrm{M})$ by heating for $1 \mathrm{~h}$ at $100{ }^{\circ} \mathrm{C}$ in closed tubes. Solutions were cooled to room temperature and metal concentrations in the extracts were determined by ICP-OES (Jobin-Yvon, Activa).

The detection limits for metal analysis by ICP-OES were $0.11,0.060,0.013,0.080,0.064,0.341$ and $0.028 \mathrm{mg} / \mathrm{kg} \mathrm{DW}$, for $\mathrm{As}, \mathrm{Cd}, \mathrm{Cr}, \mathrm{Cu}, \mathrm{Ni}, \mathrm{Pb}$ and $\mathrm{Zn}$ respectively. The analytical precision was checked by measuring in triplicate about $20 \%$ of the samples. The relative standard deviation routinely was between 1 and $8 \%$, and never higher than $10 \%$. For the quality assurance of plant analysis, the certified reference CTA-OTL-1 (Oriental Tobacco Leaves from the Bulgarian Institute for Plant Protection) was employed. Average recoveries $(n=6)$ were $91,87,66,98,85,58$, and $79 \%$ for As, $\mathrm{Cd}, \mathrm{Cr}, \mathrm{Cu}, \mathrm{Ni}, \mathrm{Pb}$ and $\mathrm{Zn}$, respectively.

\subsubsection{Snails}

The snails sampled were fasted for $48 \mathrm{~h}$ (the feces were removed after $24 \mathrm{~h}$ ) and then weighed and sacrificed by freezing at $-80^{\circ} \mathrm{C}$. After thawing, the whole soft body was removed from the shell and the foot was separated from the viscera. The viscera were studied because they are the main site of metal accumulation in snails (Hopkin, 1989). The viscera were oven-dried at $60{ }^{\circ} \mathrm{C}$ until they reached a constant weight $(\sim 0.2 / 0.3 \mathrm{~g} \mathrm{DW})$, digested in $\mathrm{HNO}_{3}\left(65 \% \mathrm{HNO}_{3}\right.$, Carlo-Erba analytical quality) as previously described (Pauget et al., 2011) and analyzed by ICP-MS. The validity of the analytical methods was checked by analyzing standard biological reference material (TORT-2, lobster hepatopancreas; National Research Council of Canada-Institute for National Measurement Standard, Ottawa, ON, Canada). The quantification limits for metal analysis by ICP-MS were 0.081, 0.003, 0.104, 0.391, 0.065, 0.009 and $0.853 \mu \mathrm{g} / \mathrm{L}$, for $\mathrm{As}, \mathrm{Cd}, \mathrm{Cr}, \mathrm{Cu}, \mathrm{Ni}, \mathrm{Pb}$ and $\mathrm{Zn}$ respectively. 
In a first approach, simple linear regressions were performed to assess the ability of soil chemical extraction methods (i.e., total concentrations and $\mathrm{CaCl}_{2}$ extraction for "available" concentrations) to predict TE accumulation by plants and snails.

Then multiple linear regression (MLR) models were established to better estimate the influence of the soil's characteristics on TE accumulation in plant and in snails (Eq. (1)):

$$
Y=x * A+y * B+, \ldots z
$$

The dependent variables (Y) were the medians of concentrations (C) of each metal(loid) in the organisms studied, after $\log (\mathrm{C}+1)$ transformation. The explanatory variables $(\mathrm{A}, \mathrm{B}, \ldots)$ were the main soil's related-parameters, i.e., $\mathrm{pH}$, cation exchange capacity $(\mathrm{CEC})$, organic carbon $\left(\mathrm{C}_{\mathrm{org}}\right)$ content, clay content, sum of exchangeable cations ( $\mathrm{SEC}: \mathrm{Al}, \mathrm{Ca}, \mathrm{Fe}, \mathrm{Mg}, \mathrm{Mn}, \mathrm{Na}$,), sands, silts, and total metal concentrations (some parameters are compositional in nature, but some were not (e.g., $\mathrm{pH}$, CEC); thus MLR were used because they allow the specific influence of each soil parameter on the biological response to be taken into account). All values, except $\mathrm{pH}$, were $\log (\mathrm{a}+1)$ transformed before data processing and $\mathrm{x}, \mathrm{y}, \ldots$ represent the coefficients of the explanatory variables.

211 Lastly, another set of MLR analyses was performed, by only considering the internal metal contents

212 in snails as the dependent variables, and by adding the metal contents in plants as supplementary 213 independent variables. The goal of this last approach was to integrate the trophic level of snails 214 (herbivorous) to better assess metal accumulation in this species.

215 For each set of regressions, the best model (i.e., the one providing the best adjusted coefficient of determination, with the lowest number of independent variables) was chosen using corrected Akaike 217 criterion -AICc- (Burnham and Anderson, 2004). All calculations were performed using the R 218 program (version 2.15.2) (R Development Core Team, 2011). 


\section{Results}

\subsection{Accumulation of TE in plants and snails}

The main distribution parameters of TE contents in plants and snails sampled on the 25 plots studied are given in Table 1. The median concentrations in $\mathrm{Cd}, \mathrm{Cu}, \mathrm{Pb}$ and $\mathrm{Zn}$ were 7- to 21-fold higher in snail viscera than in plant leaves. For $\mathrm{Cr}$ and $\mathrm{Ni}$ the median concentrations in snails and plants were about the same, while for As the measured concentrations were about 2-fold higher in plants than in snails. However there was a great variability in TE contents, both in plants and snails, as shown by the wide ranges of the data, and the median absolute deviation (MAD) values which were often close to the medians. This was obviously due to the large diversity of the studied sites, in terms of pedological characteristics and contamination levels (see S2 and S3). Consequently, we further examined the data in more details by separating values from the different sites and plots studied.

TE contents in plants and snails for each individual plot are given in Fig. 2. Comparison of accumulation profiles allowed to easily distinguishing some plots, where both plant and snail TE contents were distinctly above those measured at the other plots. For instance, at the four plots from the Metaleurop site (RW, LW, IW and IW), the Cd content in plants and snails was clearly higher. On the same site, the Pb content in both types of organisms was also abnormally high for plots LW, IW and HW. Likewise, the three plots (LCV, ICV and HCV) from the industrial SHSE site were associated with higher Cr contents in plants and snails. Lastly at the LCV (SHSE site) and CoWH (Auzon site) plots, the Ni contents were particularly high, both in plants and snails. It must be noticed that the above mentioned sites (i.e., Metaleurop, Auzon and SHSE) were all considered as highly contaminated (see $\mathrm{S} 2$ ); thus high levels of $\mathrm{Cd}, \mathrm{Pb}, \mathrm{Cr}$ and/or $\mathrm{Ni}$ in plants and snails reflected the soil contamination. Nevertheless, soil contamination was not systematically associated with high accumulation of TE in living organisms. Indeed at the plots GHM and GHF (GISFI site) both plants and snails showed low TE contents, despite a quite high soil contamination. Taken together these results highlighted that measuring TE contents in plants and snails, could clearly discriminate the plots studied, with respect to phyto- and zoo-availability. 
However in several cases there were some discrepancies between TE contents in plants and in snails. For example, the As content in snails exposed on the CoWW plot (Auzon) was very high, but no anomaly was observed in plant As content on the same plot. Likewise at the two $\mathrm{Pa}$ and Fo plots (ANDRA) the Cr content in snails was particularly high, while concentrations measured in plants were quite low. At the opposite plant contents in $\mathrm{Cd}$ and $\mathrm{Pb}$ were very high at the CoWH (Auzon) and F57 (RENECOFOR) plots respectively, while no anomaly in snail contents were evidenced. Thus, on these plots, there was no clear cut relationship between metal contents in plants and snails. This suggested that the levels of metals accumulated in both type of organisms probably depend on complex environmental factors. Consequently, to go a step further in the understanding of metal accumulation in plants and snails, we performed regression analyses taking into account the soil's parameters.

3.2. Relationships between TE contents in soil and TE accumulation in plants and snails.

A synthetic representation of TE contents in soil (total fractions extracted with $\mathrm{HF}+\mathrm{HClO}_{4}$ and "available" fractions extracted with $\mathrm{CaCl}_{2}$ ), in plants and in snails on the 25 plots studied is given in Fig. 3. This representation illustrated a complex pattern where no obvious relationship between TE in soil and in living organisms was distinguished. Consequently in order to better explain the observed TE levels in plants and snails, we first performed simple linear regression analyses and correlation studies using total and "available" TE contents in soil as explanatory variables, respectively. Results are shown in Table 2 and Table 3.

When total TE contents in soil were considered as the explanatory variables (Table 2) for accumulation in plants, significant correlations were only evidenced for $\mathrm{As}, \mathrm{Cr}, \mathrm{Ni}$ and $\mathrm{Pb}$. However, the coefficients of correlation were relatively low. The highest value was observed for $\mathrm{Cr}\left(\mathrm{r}^{2}{ }_{\text {adj }}=0.49\right)$ while for $\mathrm{As}, \mathrm{Ni}$ and $\mathrm{Pb}$ the $\mathrm{r}_{\text {adj }}^{2}$ values were comprised between 0.15 and 0.35 . For $\mathrm{Cd}, \mathrm{Cu}$ and $\mathrm{Zn}$ no significant correlations between total TE in soil and plant contents were found. In contrast for snails, internal TE concentrations were significantly correlated with total contents in soil for all elements, excepted for $\mathrm{Cu}$ (Table 2). The highest coefficient of correlation was observed for As $\left(\mathrm{r}^{2}\right.$ adj $\left.=0.63\right)$, the $r^{2}$ values for the other elements ranging between 0.14 and 0.45 . 
When "available" TE contents in soil were considered as the explanatory variables for accumulation

272 in plants and snails (Table 3), quite different results were obtained. For plants, significant, albeit 273 relatively low $\left(0.23<\mathrm{r}_{\text {adj }}^{2}<0.54\right)$, correlations were observed for $\mathrm{As}$, $\mathrm{Cd}, \mathrm{Ni}$ and $\mathrm{Pb}$, while no 274 significant correlation was evidenced for $\mathrm{Cu}$ and $\mathrm{Zn}$. For snails, significant correlations between 275 "available" TE in soil and concentrations in viscera were only found for As and $\mathrm{Cd}\left(\mathrm{r}^{2}\right.$ adj $=0.60$ and 276 0.20, respectively); for the other elements studied $(\mathrm{Cr}, \mathrm{Cu}, \mathrm{Ni}, \mathrm{Pb}$ and $\mathrm{Zn})$ no significant correlations 277 were observed.

3.3. Influence of soil properties on TE accumulation by plants and snails

Because simple regression models solely based on TE contents in soil poorly predicted the observed TE contents in plants and snails, we further performed MLR by adding the main soil characteristics as supplementary explanatory variables. Results are given in Table 4.

For plants, the addition of the soil parameters in the regression models greatly improved the estimation of $\mathrm{Cr}$ and $\mathrm{Ni}$ accumulation. The main variables influencing the accumulation of these metals were the SEC for $\mathrm{Cr}$, the $\mathrm{pH}$ for $\mathrm{Pb}$ and $\mathrm{pH}$ coupled with silt content for $\mathrm{Ni}$. On the other hand for As multiple regression model did not improve the estimation of accumulation in plants, as compared with simple models (using either total or "available" contents in soil). Lastly, for $\mathrm{Cd}, \mathrm{Cu}$ and $\mathrm{Zn}$ no statistically significant regression was found, suggesting that accumulation of these metals in plants was not dependent on the soil parameters for the set of plot studied.

289 For snails, adding the soil characteristics in the regression models improved the assessment of metal accumulation in viscera for $\mathrm{Cd}, \mathrm{Cr}, \mathrm{Ni}$ and $\mathrm{Zn}$. This increased the adjusted coefficients of correlation of approx. $10 \%, 22 \%, 12 \%$ and $10 \%$ for $\mathrm{Cd}, \mathrm{Cr}, \mathrm{Ni}, \mathrm{Zn}$ respectively. Beside total element contents in

292 soils, the main parameters that modulated metal accumulation were the SEC (for $\mathrm{Ni}$ and $\mathrm{Zn}$ ), the 293 organic carbon content (for $\mathrm{Cd}$ ) and the $\mathrm{pH}$ and $\mathrm{CaCO}_{3}$ content (for $\mathrm{Cr}$ ). On the other hand, for As and $294 \mathrm{~Pb}$ no significant influence of the soil parameters was observed. Lastly for $\mathrm{Cu}$, no significant model 295 was found. 
In order to assess the impact of the different potential sources of contamination (i.e., plants and soils) on snails' TE contents, we performed a last set of simple and multiple linear regressions. Firstly, TE contents in snails were assessed with simple regression models, using plants contents as the sole source of contamination. Secondly, we performed multiple regressions using TE concentrations in plants and in soils, as explanatory variables. Lastly, TE contents in snails were estimated taking into accounts both contamination sources and soil parameters. Results are shown in Table 5.

Simple regression analyses using plant TE contents as explanatory variables showed significant correlations with TE in snails' viscera for all the elements but $\mathrm{Cu}$, with adjusted correlation coefficients ranging from 0.21 for $\mathrm{Cr}$ to 0.56 for $\mathrm{Pb}$. Considering both sources of contamination (TE contents in soil and in plants) did not improve the simple regression models, except for $\mathrm{Cd}$ where both soil and plant TE content were significantly correlated with internal contents in snails. For $\mathrm{Ni}, \mathrm{Pb}$ and $\mathrm{Zn}$, the plant contents were the best predictors of snail's contents, while for As it was the soil total content that gave the best $\mathrm{r}^{2}$ adj. For $\mathrm{Cr}$, considering either the soil or the plants as explanatory variable gave comparable $\mathrm{r}^{2}$ adj.

311 Lastly using more complex multiple regression models, taking into account the two sources of contamination plus the soil parameters (Table 5), only improved the assessment of $\mathrm{Cd}, \mathrm{Cr}$ and $\mathrm{Pb}$ accumulation. For $\mathrm{Cd}$, both soil content, plant content and soil organic carbon significantly influenced

314 the concentration in snail's viscera. For $\mathrm{Cr}$, the observed increased in the $\mathrm{r}^{2}$ adj was only due to the soil's 315 parameters $\left(\mathrm{pH}\right.$ and $\left.\mathrm{CaCO}_{3}\right)$. For $\mathrm{Pb}$, the concentration in snail's viscera was significantly influenced 316 by plant content and soil parameters (i.e., pH) but not by total content in soil. For the other TE (As, $317 \mathrm{Cu}, \mathrm{Ni}$ and $\mathrm{Zn}$ ), complex multiple regression models did not improve the $\mathrm{r}_{\text {adj }}^{2}$ values, as compared with those using only soil or plant TE contents as explanatory variables. 


\section{Discussion}

Although separating bioavailability into three operational insights (i.e., environmental availability, environmental bioavailability and toxicological availability) allows to clarify the concept and to propose various measurement methods, the underlying physical, chemical and biological factors that ultimately govern the transfer of TE from a contaminated habitat to living organisms are still poorly understood. In particular the question remains to know the relationships between environmental availability and environmental bioavailability and, ultimately, how these descriptors should be handled in a view of environmental risk assessment. In this work, we studied the correlations between TE extracted by standardized chemical methods and those actually accumulated in two model organisms (plants and snails). We also investigated the influence of soil properties and contamination source on TE bioaccumulation.

4.1. Standardized chemical methods for TE extraction from soils poorly predict TE accumulation in plants and snails

Classically, two different points of view can be considered for TE analysis in soil, with the aim of risk assessment for ecological receptors. The default assumption is that the totality of TE present in the soil could pose a risk at a short-, medium- or long-term scale, i.e., that availability could be $100 \%$. A less conservative assumption is that only part of total TE is actually bioavailable and thus poses a risk to living organisms. From these points of view, a number of total and partial extraction schemes have been designed for soil analysis in risk assessment procedures. Among the most commonly used methods, are the standardized $\mathrm{HF}-\mathrm{HClO}_{4}$ mineralization for total TE (AFNOR, 1996), and the $0.01 \mathrm{M}$ $\mathrm{CaCl}_{2}$ extraction, for "available" TE (NEN 5704, 1996). These are the methods we retained in this work.

Our correlation studies showed that the total TE contents in soils $\left(\mathrm{HF}-\mathrm{HClO}_{4}\right.$ extraction) were poorly correlated to the concentrations of TE measured in plants. Indeed on average, only $18 \%$ of the variability in plant TE contents was explained by the total contents in soils. There were however noticeable differences between elements, with correlation coefficients ranging from 0 for $\mathrm{Cd}, \mathrm{Cu}$ and 
$\mathrm{Zn}$, to $>0.3$ for $\mathrm{Cr}$ and $\mathrm{Pb}$. To consider "available" TE contents in soils $\left(\mathrm{CaCl}_{2}\right.$ extraction) was clearly a better proxy for $\mathrm{Cd}\left(\mathrm{r}^{2}\right.$ adj $\left.=0.3\right)$ and, in a lesser extent, for $\mathrm{Ni}$ and $\mathrm{Pb}$. This is in accordance with the basic assumption that plants take up TE from the soil solution (Degryse et al., 2009 and Smethurst, 2000), and that $\mathrm{CaCl}_{2}$ extractions better reflect this soil compartment than do total extractions (KabataPendias, 2004, Meers et al., 2007 and Römkens et al., 2009). However $\mathrm{CaCl}_{2}$ extractions still did not 350 detect any correlation between soil and plant contents for $\mathrm{Cu}$ and $\mathrm{Zn}$, while for As, plant contents remained better explained by total than by "available" TE in soils.

For snails, about $29 \%$ of the variability of TE contents in viscera was explained by total concentrations in soil; at the opposite, "available" TE explained only $11 \%$ of the variability of viscera's contents. The greater influence of soil total TE content, as compared to "available" concentrations, on snail's internal TE levels could be partly due to its foraging mode which multiplies the sources of exposure. Indeed, in addition to their plant-based diet, snails also ingest significant amounts of soil particles to satisfy their physiological needs (Gomot et al., 1989). This could allow snails to pick up quite strongly bounded TE on soil constituents (Pauget et al., 2012). Thus, as previously shown for earthworms (van Gestel, 2008), total soil concentrations are a better indicator of the amounts of TE that are available for snails, than the $\mathrm{CaCl}_{2}$ extractable pools. However, as observed for plants, there were clear cut differences between elements, and $\mathrm{Cu}, \mathrm{Ni}$ and $\mathrm{Zn}$ concentrations in viscera were not, or slightly $\left(\mathrm{r}^{2}<0.15\right)$, correlated with soil contents.

363 It is interesting to note that, whatever the extraction method used and the organism considered, there was no, or very low, correlations between the content in soils and the content in living organisms, for those elements that are essential for nutrition (i.e., $\mathrm{Cu}, \mathrm{Ni}$ and $\mathrm{Zn}$ ). This is likely due to the complex biological processes regulating homeostasis of essential elements, allowing living organisms to maintain almost stable internal levels under a certain range of external concentrations (Bargagli, 1998 and Menta and Parisi, 2001). Thus, it is only when homeostasis can no be longer controlled that the internal levels of essential elements will rise significantly. It is obvious that chemical extraction methods cannot take into account such biological response, making these methods poor proxies for 
assessing environmental bioavailability of essential elements. At the opposite, for non essential TE $(\mathrm{As}, \mathrm{Cd}, \mathrm{Cr}, \mathrm{Pb})$ whose concentrations in living organisms are not under strict homeostatic control, correlations between contents in soil and in organisms were better, but were clearly dependent on the fraction of TE (total $v s$ "available" fraction) and the organism considered (plants $v s$ snails).

Thus, as already emphasized by a number of authors for different types of soil, contamination levels and living organisms (Lopes et al., 2012, McLaughlin et al., 2000, Mourier et al., 2011, Murphy et al., 2000, Remon et al., 2005 and Van Gestel, 2008), these results confirm that neither total soil concentrations nor "available" concentrations give enough information to foresee the actual environmental bioavailability of TE on contaminated sites.

\subsection{Factors modulating TE accumulation are different for plant and snails}

It is well known that the speciation of TE in soils depends on the soil's characteristics such as $\mathrm{pH}$, redox potential, CEC or organic matter content and quality (Park et al., 2011, Unamuno et al., 2009 and Zeng et al., 2011). Thus, we hypothesized that beside total or "available" TE contents in soils, as determined by chemical extraction methods, the accumulation of TE in plants and snails could be partly correlated to some soil parameters. Moreover, because snails are mostly herbivorous, we postulated that TE accumulation in viscera could be closely linked to plant contamination.

When plants were considered, MLR models indeed improved the assessment of $\mathrm{Cr}$ and $\mathrm{Ni}$ accumulation, and highlighted that soil factors such as $\mathrm{pH}$, carbonates or total content of exchangeable cations may play a significant role in the phytoavailability of TE. However for the other TE studied (As, $\mathrm{Cd}, \mathrm{Cu}, \mathrm{Pb}$ and $\mathrm{Zn}$ ) the MLR did not give better correlation coefficients than simpler models using only "available" soil contents as explanatory variable. At the opposite for snails, considering the soil parameters and/or plant contents in the regression models improved the assessment of all TE, but

393 As and $\mathrm{Cu}$. As a rule, TE contents in snail viscera were mostly correlated to plant contents, except for

$394 \mathrm{Cu}$. This is in agreement with the results of Scheifler et al. (2006) who showed that up to 90\% of Cd 395 accumulated by snails came from plants. Internal TE contents in snails were also correlated to total contents in soil (As, $\mathrm{Cd}, \mathrm{Cr})$ and/or to organic carbon $(\mathrm{Cd}), \mathrm{pH}(\mathrm{Cr}, \mathrm{Pb})$ and carbonates $(\mathrm{Cr})$. 

and snails, but rather to compare the main parameters explaining variations in TE contents in both organisms. Our results showed that TE contents in plants and snails were depending on very different parameters. These differences are obviously due to the different exposition pathways, and finally to the specific physiology of each type of organism. In fact, because of the development of their root system, plants can accumulate TE from deeper soil layers than do snails, which are only exposed to the topsoil (Berger and Dallinger, 1993). Moreover, the activity of plant roots and associated microorganisms may trigger localized soil modifications, leading to a significant increase or decrease of $\mathrm{pH}$, redox potential and/or organic matter content (Ehrenfeld, 2013). Thus, these so-called rhizosphere processes, can considerably modify the speciation of TE (Kabata-Pendias, 2004) and their availability for plants; at the opposite, snails do not significantly modify soil properties and have very likely no effect on TE speciation (Coeurdassier et al., 2007). Also, the fate of TE in plants and snails is very different, in that snails are able to excrete some accumulated TE (Gimbert et al., 2008b), while in plants they are stored in the roots or above ground tissues but are rarely excreted (Weis and Weis, 2004). Lastly a major difference between these biological receptors lies in their source of contamination. Indeed plants are mainly exposed to TE via the soil, whereas snails are exposed to both soil and contaminated plants. Our results indeed confirmed that both sources of contamination had a significant influence on snail's TE content.

It is widely admitted today that assessing and managing polluted soils on the sole basis of their total contaminant concentrations (IEM, 2007, ISO 17402, 2008 and US EPA, 2007) may lead to inaccurate 418 conclusions and decisions (Brand et al., 2013, Mourier et al., 2011 and Van Gestel, 2008), resulting in 419 misestimating the actual risk for biological receptors. Thus considering the bioavailability of 420 contaminants could be a more relevant approach, as this integrates all aspects modulating their transfer to living organisms (Fig. 4) (van Gestel, 2008). Given this, it is now argued that integrating the concept of bioavailability in risk assessment methodologies is a necessity (ISO, 17402, 2008). In this 
objective the use of $\mathrm{CaCl}_{2}$ extraction is usually presented as a good chemical proxy for bioavailability.

However in this study we showed that such a chemical extraction poorly estimated TE accumulation in plants and snails in large scale in situ experiments, i.e., considering numerous elements, contamination levels and soil types. This confirms the conclusions of several authors ( Feng et al., 2005 and Van Gestel, 2008) who emphasized the limitation of the $\mathrm{CaCl}_{2}$ method for the prediction of TE bioavailability in some field situations. To fill this gap a number of alternative weak extraction procedures have been proposed so far, each focusing on particular elements, soil types or biological receptors ( Mourier et al., 2011 and Smith et al., 2010). This underlines the difficulty to find a universal chemical extractant that could predict TE bioavailability. In fact, whatever the extractant used, one of the major limitations of the "chemical extraction" approach to assess bioavailability, is that it intrinsically considers the soil as the sole source of exposure. This may be a correct assumption for plants, but this is obviously not true for numerous other organisms whose nutrition does not exclusively depend on soil. For instance in snails, we showed that considering various exposition pathways according to the trophic level of the target organism, strongly improved the prediction of accumulation of several TE in viscera. This result highlights the importance of taking into account all contamination sources, and not only the total or "available" TE contents in soil, when assessing the bioavailability of contaminants on a given site. Consequently, although chemical extraction methods are routinely used with the underlying idea that they can give a general insight into metal bioavailability, they actually only inform about the easiness of metal leaching from soil by chemical

442 weak extractions, which is a measure of the environmental availability and not of the actual 443 bioavailability. So, owing that the accumulation of TE in living organisms depends on both the metal 444 speciation in soil and the physiological traits of the target organisms, the study of bioindicators could be a relevant complement to chemical procedures, to get insights into TE bioavailability on contaminated sites (Reeves and Chaney, 2008).

In this study we considered two types of bioindicators (plants and snails), representative of two 448 trophic levels. Indeed we assumed that coupling biological measures, by permitting the differences 
between organisms to be taken into account, should allow a more accurate assessment of TE bioavailability and a better site characterization. For bioindication using plants, the "composite sample" strategy (Remon et al., 2013) makes easy the prospection of large areas and allows to overcome interspecific variations. Consequently, such a passive bioindication approach informs on the global phytoavailability of TE and their potential transfer toward primary consumers. On the other hand, bioindication using snails gives information about TE transfer to a specific link of the food chain integrating multiple contamination sources (i.e., soil and plants) and being a prey for a number of carnivorous species (Barker, 2004 and Scheifler et al., 2006). The snail-watch approach permits accurate between-sites comparisons of TE bioavailability (Beeby and Richmond, 2003) as it uses laboratory-born and calibrated animals. This active bioindication strategy informs on a speciesspecific zooavailability of TE, allowing their potential transfer toward higher levels of the trophic webs to be partly anticipated.

However, even though both bioindication strategies have many advantages, they also pose some questions or present some limits (Varrault and Bermond, 2011). For instance, because of the potential adaptation of plants to contaminated soils (Schipper et al., 2011), TE phytoavailability on a given site may change if plant communities are modified. Likewise, because snails only inform on the bioavailability of TE inside the small area of the microcosms, the study of large and heterogeneous sites may be relatively time consuming. Lastly it must be kept in mind that bioavailability of TE cannot be quantified by a single value, as it closely depends on the organism of interest. Nevertheless, accumulation bioindicators provide specific information about the extent of actual TE transfer toward living organisms; consequently they allow a "physiologically defined" approach (Peijnenburg et al., 2007) for measuring bioavailability. Thus, together with the classical chemical methods for assessing environmental availability, actual uptake studies could be used as a guideline to assess the environmental bioavailability of TE. These dual chemical and biological approaches could constitute a more accurate way for raising (or decreasing) the alarm on soil quality for environmental risk assessment. 


\section{Supporting Information:}

S 2: Total ( $\mathrm{HF}+\mathrm{HClO}_{4}$ extraction) and "available" $\left(\mathrm{CaCl}_{2}\right.$ extraction) $\mathrm{TE}$ contents at the 25 plots below the detection limit

\section{ACKNOWLEDGMENT}

This work received support from the Agence pour le Développement et la Maîtrise de l'Energie

(ADEME, France) (1281C0035). C. Grand, A. Bispo and L. Galsolmies (ADEME) are particularly acknowledged, as well as G. Pérès (Univ. Rennes I) for the coordination of the program. The authors acknowledge T. Beguiristain (Univ. Lorraine), S. Conil (ANDRA), F. Douai (ISA Lille), M. Guernion (Univ. Rennes I), A. Hitmi (IUT Clermont-Ferrand) and S. Houot (INRA Versailles) for hosting at the experimental sites.

\section{ABBREVIATIONS}

CEC, cation exchange capacity; MAD, median absolute deviation; MLR, multiple linear regression;

OM, organic matter; TE, trace element; SEC, sum of exchangeable cation

\section{REFERENCES}

AFNOR, 1996. Qualité des sols - Méthodes chimiques - sols sédiments, mise en solution totale par attaque acide - NF X31-147. Association Française de Normalisation, Paris, France.

Bargagli, R., 1998. Trace Elements in Terrestrial Plants: An Ecophysiological Approach to Biomonitoring and Biorecovery. Lavoisier.

Barker, G.M., 2004. Natural enemies of terrestrial mollusks. CABI Publishing, Wallingford, UK. 
Beeby, A., Richmond, L., 2003. Do the soft tissues of Helix aspersa serve as a quantitative sentinel of predicted free lead concentrations in soils? Appl. Soil Ecol. 22, 159-165.

Berger, B., Dallinger, R., 1993. Terrestrial snails as quantitative indicators of environmental metal pollution. Environ. Monit. Assess. 25, 65-84.

Brand, E., Lijzen, J., Peijnenburg, W., Swartjes, F., 2012. Possibilities of implementation of bioavailability methods for organic contaminants in the Dutch Soil Quality Assessment Framework. J. Hazard. Mater.

Burnham, K.P., Anderson, D.R., 2004. Multimodel Inference Understanding AIC and BIC in Model Selection. Sociol. Methods Resarch 32, 261-304.

Carlon, C., 2007. Derivation methods of soil screening values in Europe. A review and evaluation of national procedures towards harmonisation. JRC Scientific and Technical Reports. Europeen Commission (No. eur 22805 EN).

Coeurdassier, M., Scheifler, R., de Vaufleury, A., Crini, N., Saccomani, C., Du Mont, L.S., Badot, P.M., 2007. Earthworms influence metal transfer from soil to snails. Appl. Soil Ecol. 35, 302310 .

Dallinger, R., Berger, B., 1992. Bio-monitoring in the urban Environment, in: Bonotto, S., Nobili, R., Revoltella, R.P. (Eds.), Biological Indicators for Environmental Monitoring. Ares-Serono Symposia n²7, Rome, Italie, pp. 227-242.

Degryse, F., Smolders, E., Parker, D.R., 2009. Partitioning of metals (Cd, Co, Cu, Ni, Pb, Zn) in soils: concepts, methodologies, prediction and applications - a review. Eur. J. Soil Sci. 60, 590-612. doi:10.1111/j.1365-2389.2009.01142.x

Ehrenfeld, J.G., 2013. Plant-Soil Interactions, in: Simon A. Levin (Ed.), Encyclopedia of Biodiversity (Second Edition). Academic Press, Waltham, pp. 109-128.

Feng, M.-H., Shan, X.-Q., Zhang, S., Wen, B., 2005. A comparison of the rhizosphere-based method with DTPA, EDTA, $\mathrm{CaCl}_{2}$, and $\mathrm{NaNO}_{3}$ extraction methods for prediction of bioavailability of metals in soil to barley. Environ. Pollut. 137, 231-240.

Fritsch, C., Coeurdassier, M., Gimbert, F., Crini, N., Scheifler, R., de Vaufleury, A., 2011. Investigations of responses to metal pollution in land snail populations (Cantareus aspersus and Cepaea nemoralis) from a smelter-impacted area. Ecotoxicology 20, 739-759.

Gimbert, F., de Vaufleury, A., Douay, F., Scheifler, R., Coeurdassier, M., Badot, P.-M., 2006. Modelling chronic exposure to contaminated soil: A toxicokinetic approach with the terrestrial snail Helix aspersa. Environ. Int. 32, 866-875.

Gimbert, F., Mench, M., Coeurdassier, M., Badot, P.-M., de Vaufleury, A., 2008a. Kinetic and dynamic aspects of soil-plant-snail transfer of cadmium in the field. Environ. Pollut. 152, $736-745$.

Gimbert, F., Vijver, M.G., Coeurdassier, M., Scheifler, R., Peijnenburg, W., Badot, P.M., de Vaufleury, A., 2008b. How subcellular partitioning can help to understand heavy metal accumulation and elimination kinetics in snails. Environ. Toxicol. Chem. 27, 1284-1292. 
Gomot, A., Gomot, L., Boukraa, S., Bruckert, S., 1989. Influence of soil on the growth of the land snail Helix aspersa - An experimental study of the absorption route for the simulating factors. J. Molluscan Stud. 55, 1-7.

Gomot-de Vaufleury, A., 2000. Standardized Growth Toxicity Testing $(\mathrm{Cu}, \mathrm{Zn}, \mathrm{Pb}$, and Pentachlorophenol) with Helix aspersa. Ecotoxicol. Environ. Saf. 46, 41-50.

Harmsen, J., 2007. Measuring bioavailability: From a scientific approach to standard methods. J. Environ. Qual. 36, 1420-1428. doi:10.2134/jeq2006.0492

Hopkin, S.P., 1989. Ecophysiology of metals in terrestrial invertebrates. Elsevier, New York.

IEM, 2007. La démarche d'interprétation de l'état des milieux. http://www.developpementdurable.gouv.fr/IMG/pdf/outil_IEM.pdf2012 [WWW Document].

ISO 17402, 2008. Soil quality - Requirements and guidance for the selection and application of methods for the assessment of bioavailabilty of contaminants in soil and soil materials. International Organization for Standardization, Geneva, Switzerland.

Jeffery, S., Gardi, C., Jones, A., Montanarella, L., Marmo, L., Miko, L., Ritz, K., Peres, G., Römbke, J., van der Putten, W.H., 2010. European Atlas of Soil Biodiversity. European Commission. Office of the European Union, Luxembourg.

Kabata-Pendias, A., 2004. Soil-plant transfer of trace elements - an environmental issue. Geoderma 122, 143-149. doi:10.1016/j.geoderma.2004.01.004

Lanno, R., Wells, J., Conder, J., Bradham, K., Basta, N., 2004. The bioavailability of chemicals in soil for earthworms. Ecotoxicol. Environ. Saf. 57, 39-47.

Le Guédard, M., Faure, O., Bessoule, J.-J., 2012. Soundness of in situ lipid biomarker analysis: Early effect of heavy metals on leaf fatty acid composition of Lactuca serriola. Environ. Exp. Bot. $76,54-59$.

Lopes, C., Herva, M., Franco-Uria, A., Roca, E., 2012. Multicorrelation models and uptake factors to estimate metal concentrations from soil and metal in plants in pasturelands fertilized with manure. Environ. Pollut. 17-22.

McLaughlin, M.J., Zarcinas, B.A., Stevens, D.P., Cook, N., 2000. Soil testing for heavy metals. Commun. Soil Sci. Plant Anal. 31, 1661-1700.

Meers, E., Samson, R., Tack, F.M.G., Ruttens, A., Vandegehuchte, M., Vangronsveld, J., Verloo, M.G., 2007. Phytoavailability assessment of heavy metals in soils by single extractions and accumulation by Phaseolus vulgaris. Environ. Exp. Bot. 60, 385-396. doi:10.1016/j.envexpbot.2006.12.010

Menta, C., Parisi, V., 2001. Metal concentrations in Helix pomatia, Helix aspersa and Arion rufus: a comparative study. Environ. Pollut. 115, 205-208. doi:10.1016/S0269-7491(01)00110-5

Moriarty, F., 1999. Ecotoxicology: The study of pollutants in Ecosystems, Third Edition. Academic Press. 
Mourier, B., Fritsch, C., Dhivert, E., Gimbert, F., Coeurdassier, M., Pauget, B., Vaufleury, A. de, Scheifler, R., 2011. Chemical extractions and predicted free ion activities fail to estimate metal transfer from soil to field land snails. Chemosphere 85, 1057-1065.

Murphy, A.P., Coudert, M., Barker, J., 2000. Plants as biomarkers for monitoring heavy metal contaminants on landfill sites using sequential extraction and inductively coupled plasma atomic emission spectrophotometry (ICP-AES). J. Environ. Monit. 2, 621-627.

Naidu, R., Semple, K.T., Megharaj, M., Juhasz, A.L., Bolan, N.S., Gupta, S.K., Clothier, B.E., Schulin, R., 2008. Chapter 3 Bioavailability: Definition, assessment and implications for risk assessment, in: A.E. Hartemink, A.B.M. and R.N. (Ed.), Developments in Soil Science. Elsevier, pp. 39-51.

NEN 5704, 1996. Soil - Sample preparation of soil - Extraction with a calcium chloride solution (0.01 $\mathrm{mol} / \mathrm{L}) 4$.

Park, J.H., Lamb, D., Paneerselvam, P., Choppala, G., Bolan, N., Chung, J.-W., 2011. Role of organic amendments on enhanced bioremediation of heavy metal(loid) contaminated soils. J. Hazard. Mater. 185, 549-574.

Pauget, B., Gimbert, F., Coeurdassier, M., Crini, N., Pérès, G., Faure, O., Douay, F., Hitmi, A., Beguiristain, T., Alaphilippe, A., Guernion, M., Houot, S., Legras, M., Vian, J.-F., Hedde, M., Bispo, A., Grand, C., de Vaufleury, A., 2013. Ranking field site management priorities according to their metal transfer to snails. Ecol. Indic. 29, 445-454.

Pauget, B., Gimbert, F., Coeurdassier, M., Scheifler, R., de Vaufleury, A., 2011. Use of chemical methods to assess $\mathrm{Cd}$ and $\mathrm{Pb}$ bioavailability to the snail Cantareus aspersus: a first attempt taking into account soil characteristics. J. Hazard. Mater. 192, 1804-1811.

Pauget, B., Gimbert, F., Scheifler, R., Coeurdassier, M., de Vaufleury, A., 2012. Soil parameters as key factor to predict metal bioavailability to snails using chemical extractants. Sci. Total Environ. 431, 413-425.

Peakall, D., Burger, J., 2003. Methodologies for assessing exposure to metals: speciation, bioavailability of metals, and ecological host factors. Ecotoxicol. Environ. Saf. 56, 110-121.

Peijnenburg, W., Posthuma, L., Eijsackers, H.J.P., Allen, H.E., 1997. A conceptual framework for implementation of bioavailability of metals for environmental management purposes. Ecotoxicol. Environ. Saf. 37, 163-172.

Peijnenburg, W., Zablotskaja, M., Vijver, M.G., 2007. Monitoring metals in terrestrial environments within a bioavailability framework and a focus on soil extraction. Ecotoxicol. Environ. Saf. 67, 163-179. doi:10.1016/j.ecoenv.2007.02.008

G. Pérès, F. Vandenbulcke, M. Guernion, M. Hedde, T. Beguiristain, F. Douay, S. Houot, D. Piron, A. Richard, A. Bispo, C. Grand, L. Galsomies, D. Cluzeau 2011. Earthworm indicators as tools for soil monitoring, characterization and risk assessment. An example from the national Bioindicator programme (France). Pedobiologia, 54 (2011), pp. S77-S87

Plassart, P., Vinceslas, M.A., Gangneux, C., Mercier, A., Barray, S., Laval, K., 2008. Molecular and functional responses of soil microbial communities under grassland restoration. Agric. Ecosyst. Environ. 127, 286-293. 
Qingdong, K., Costa, M., Kazantzis, G., 2007. Carcinogenicity of metal compounds, in: Nordberg G.F., Foxler B.A., Nordberg M., Friberg L.T. Handbook on the Toxicology of Metals. Elsevier, p. 949.

Rabitsch, W.B., 1996. Metal accumulation in terrestrial pulmonates at a lead / zinc smelter site in Arnoldstein, Austria. Bull. Environ. Contam. Toxicol. 56, 734-741.

R Development Core Team, 2011. R: a language and environment for statistical computing. R Foundation for Statistical Computing, Vienna, Austria.

Reeves, P.G., Chaney, R.L., 2008. Bioavailability as an issue in risk assessment and management of food cadmium: A review. Sci. Total Environ. 398, 13-19.

Remon, E., Bouchardon, J.-L., Cornier, B., Guy, B., Leclerc, J.-C., Faure, O., 2005. Soil characteristics, heavy metal availability and vegetation recovery at a former metallurgical landfill: Implications in risk assessment and site restoration. Environ. Pollut. 137, 316-323. doi:10.1016/j.envpol.2005.01.012

Remon, E., Bouchardon, J.L., Le Guédard, M., Bessoule, J.J., Conord, C., Faure, O., 2013. Are plants useful as accumulation indicators of metal bioavailability? Environ. Pollut. 175, 1-7.

Römkens, P.F.A.M., Guo, H.Y., Chu, C.L., Liu, T.S., Chiang, C.F., Koopmans, G.F., 2009. Prediction of Cadmium uptake by brown rice and derivation of soil-plant transfer models to improve soil protection guidelines. Environ. Pollut. 157, 2435-2444. doi:10.1016/j.envpol.2009.03.009

Scheifler, R., Brahim, M.B., Gomot-de Vaufleury, A., Carnus, J.M., Badot, P.M., 2003. A field method using microcosms to evaluate transfer of $\mathrm{Cd}, \mathrm{Cu}, \mathrm{Ni}, \mathrm{Pb}$ and $\mathrm{Zn}$ from sewage sludge amended forest soils to Helix aspersa snails. Environ. Pollut. 122, 343-350.

Scheifler, R., de Vaufleury, A., Cœurdassier, M., Crini, N., Badot, P.-M., 2006. Transfer of Cd, Cu, $\mathrm{Ni}, \mathrm{Pb}$ and $\mathrm{Zn}$ in a "soil - plant - invertebrate" food chain: a microcosm study. Environ. Toxicol. Chem. 25, 815-822.

Schipper, A.M., Lotterman, K., Leuven, R.S.E.W., Ragas, A.M.J., de Kroon, H., Hendriks, A.J., 2011. Plant communities in relation to flooding and soil contamination in a lowland Rhine River floodplain. Environ. Pollut. 159, 182-189.

Science Communication Unit, 2013. Science for Environment Policy In-depth. Report: Soil Contamination: Impacts on Human Health. Report produced for the European Commission DG Environment, September 2013. University of the West of England, Bristol. Available at: http://ec.europa.eu/science-environment-policy.

Semple, K.T., Doick, K.J., Jones, K.C., Burauel, P., Craven, A., Harms, H., 2004. Peer Reviewed: Defining Bioavailability and Bioaccessibility of Contaminated Soil and Sediment is Complicated. Environ. Sci. Technol. 38, 228A-231A. doi:10.1021/es040548w

Smethurst, P.J., 2000. Soil solution and other soil analyses as indicators of nutrient supply: a review. For. Ecol. Manag. 138, 397-411. doi:10.1016/S0378-1127(00)00426-6

Smith, B.A., Greenberg, B., Stephenson, G.L., 2010. Comparison of biological and chemical measures of metal bioavailability in field soils: Test of a novel simulated earthworm gut extraction. Chemosphere 81, 755-766. 
Unamuno, V.I.R., Meers, E., Du Laing, G., Tack, F.M.G., 2009. Effect of Physicochemical Soil Characteristics on Copper and Lead Solubility in Polluted and Unpolluted Soils. Soil Sci. 174, 601-610. doi:10.1097/SS.0b013e3181bf2f52

US EPA, 2007. Framework for Metal Risk Assessment EPA 120/R-07/001.

Van Gestel, C.A.M., 2008. Physico-chemical and biological parameters determine metal bioavailability in soils. Sci. Total Environ. 406, 385-395.

Van Gestel, C.A.M., Koolhaas, J.E., Hamers, T., van Hoppe, M., van Roovert, M., Korsman, C., Reineckec, S.A., 2009. Effects of metal pollution on earthworm communities in a contaminated floodplain area: Linking biomarker, community and functional responses. Environ. Pollut. 157, 895-903. doi:10.1016/j.envpol.2008.11.002

Varrault, G., Bermond, A., 2011. Kinetics as a tool to assess the immobilization of soil trace metals by binding phase amendments for in situ remediation purposes. J. Hazard. Mater. 192, 808-812.

Vergé, X., Chapuis, A., Delpoux, M., 2002. Bioindicator reliability: the example of Bel W3 tobacco (Nicotiana tabacum L.). Environ. Pollut. 118, 337-349.

Weis, J.S., Weis, P., 2004. Metal uptake, transport and release by wetland plants: implications for phytoremediation and restoration. Environ. Int. 30, 685-700.

Zeng, F., Ali, S., Zhang, H., Ouyang, Y., Qiu, B., Wu, F., Zhang, G., 2011. The influence of pH and organic matter content in paddy soil on heavy metal availability and their uptake by rice plants. Environ. Pollut. 159, 84-91. 
672

673

\section{FIGURES}

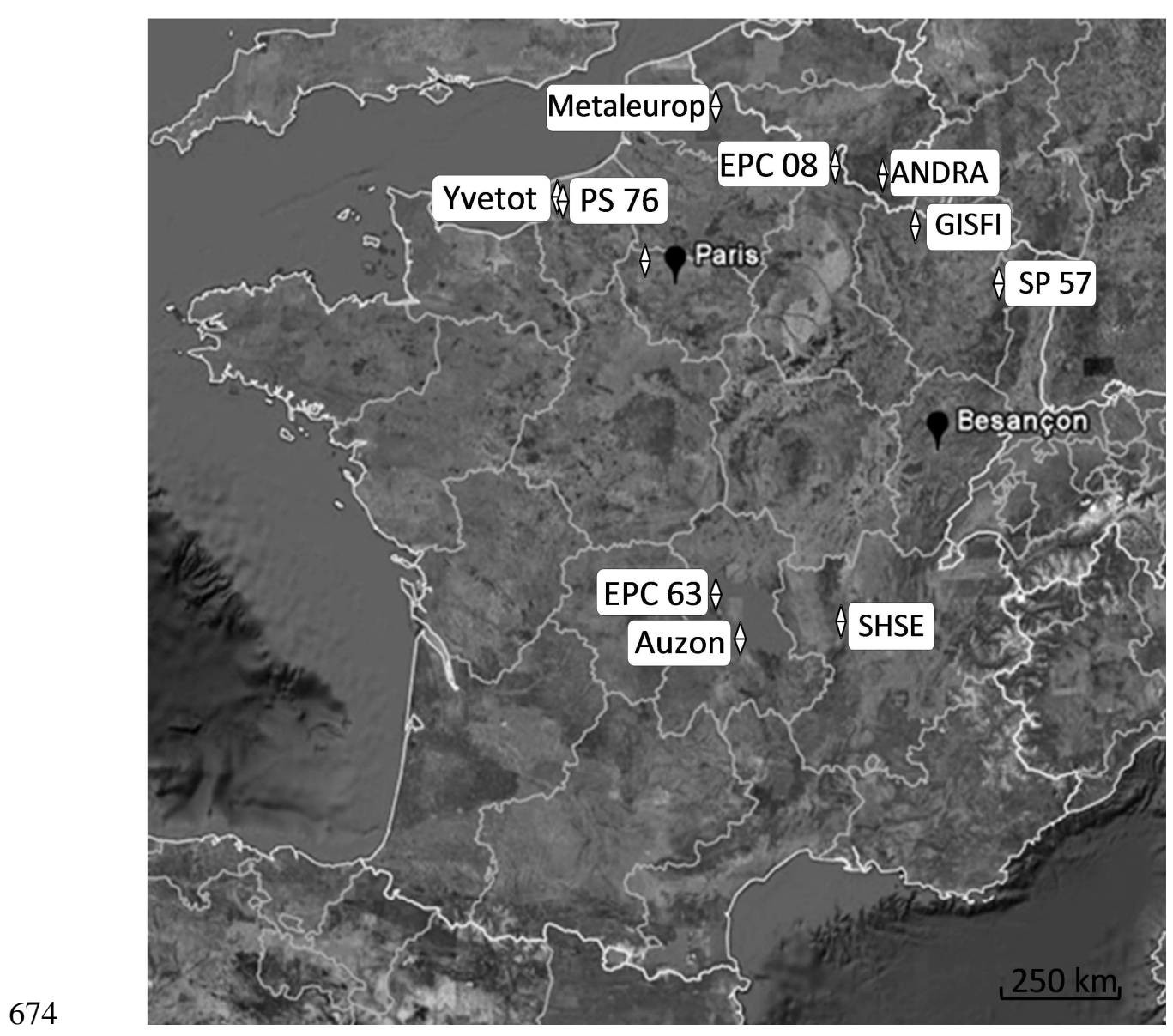

675 676

Figure 1: Sites localization. http://ecobiosoil.univ-rennes1.fr/ADEME-Bioindicateur/ 

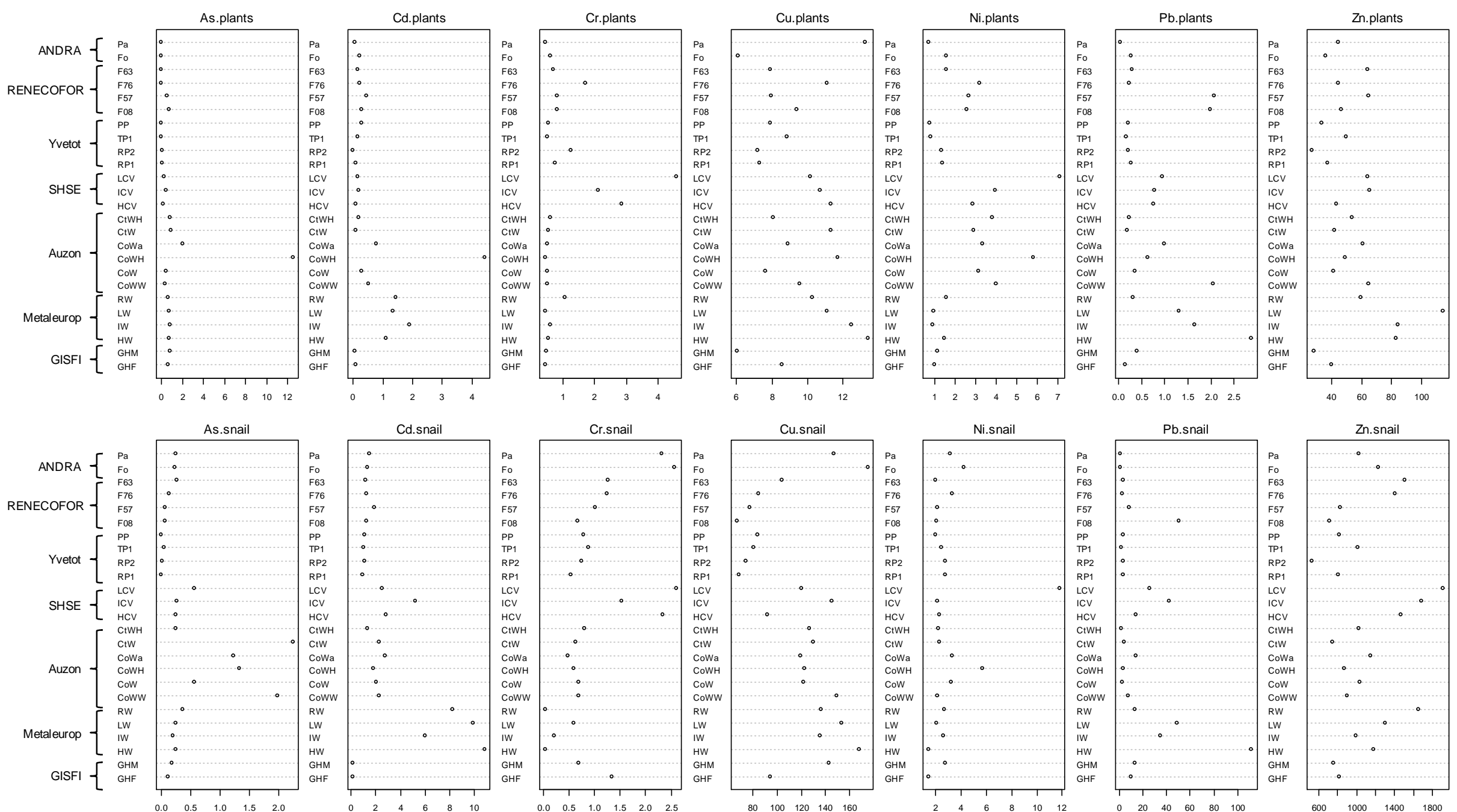

Figure 2: TE contents $\left(\mathrm{mg} \mathrm{kg}^{-1}\right.$ ) in plants (up) and snails (down) sampled on 25 plots from 7 sites (median values, $\mathrm{n}=5$ for plants, $\mathrm{n}=6$ for snails). 

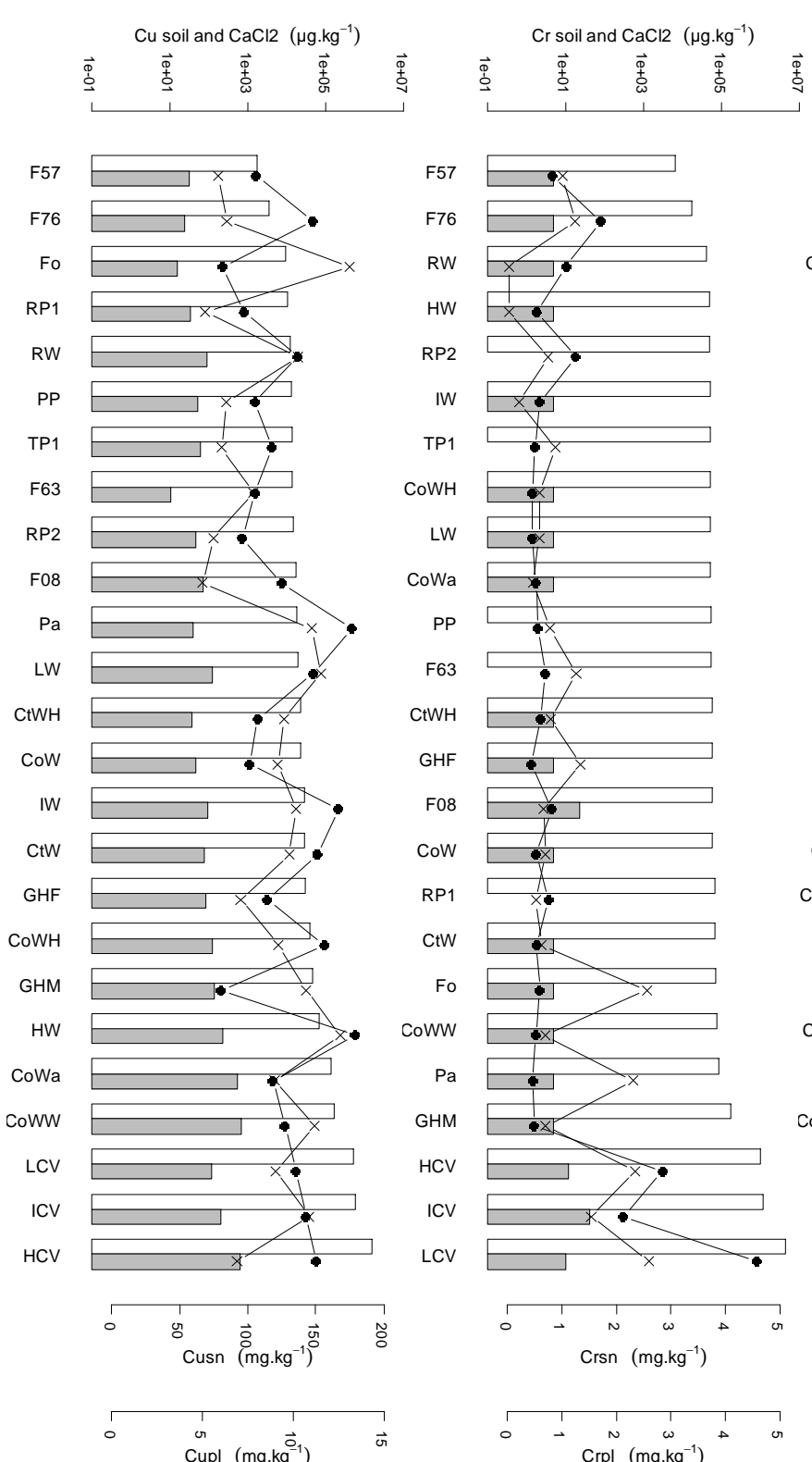

$5 5 7 \longdiv { x }$

F76

HW $\times$

RP2

Iw

TP1

ij

Lw $\prod_{x}$

PP

F63

CtwH $\frac{i^{x}}{x}$

GHF $: x$

F08

cow $\frac{1}{0}$

RP1

Ctw $\gamma_{\alpha}$

Fo

Coww

$\mathrm{Pa} ! \mathrm{X}_{\mathrm{X}}$

GHM $\square$

$\mathrm{HCV}$

ICV

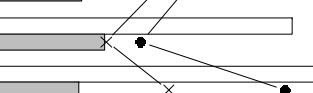

LCV

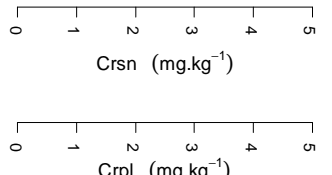

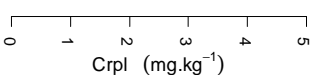

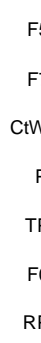

F57

F76

$\mathrm{CtWH}$

PP

TP1

RP1

RP2

ix

$\mathrm { Pa } \longdiv { \mathrm { T } }$

GHF $\frac{1}{x}$

$\mathrm{Ctw} \times \mathrm{x}$

cow $\frac{1}{x}$

RW

GHM

CoWH $\frac{x}{0.0}$.

LCV $\frac{1}{x+x^{x}}$

LW

Cowa ax

ICV $\rightarrow$

IW

$\mathrm{HCV}$

$\mathrm{HW}$

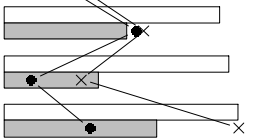

$\circ \quad$ or $\overrightarrow{0} \quad \vec{v}$

Cdsn (mg.kg-1)

- $\quad \underset{\omega}{\infty} \underset{\omega}{\infty}+\infty$
As soil and $\mathrm{CaCl} 2\left(\mu \mathrm{gg} \cdot \mathrm{kg}^{-1}\right)$

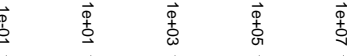

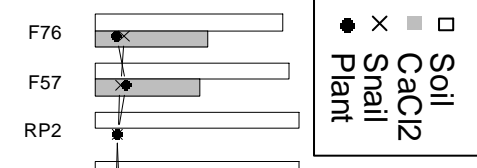

RP1

RW ox

TP1

i

663

Fo

$\mathrm{Pa} \stackrel{\mathrm{X}}{\mathrm{X}}$

F08

LCV

GHF

HW

(II

ICV

GHM

CtWH

HCV $\prod_{0,1}$

$\mathrm{Ctw}$

cow 0

CoWH

Cowa $\frac{x}{x}$

coww $\int_{x}$

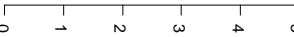
Assn (mg.kg

$0 \quad \frac{1}{\vec{o}_{1}} \quad \vec{v}$




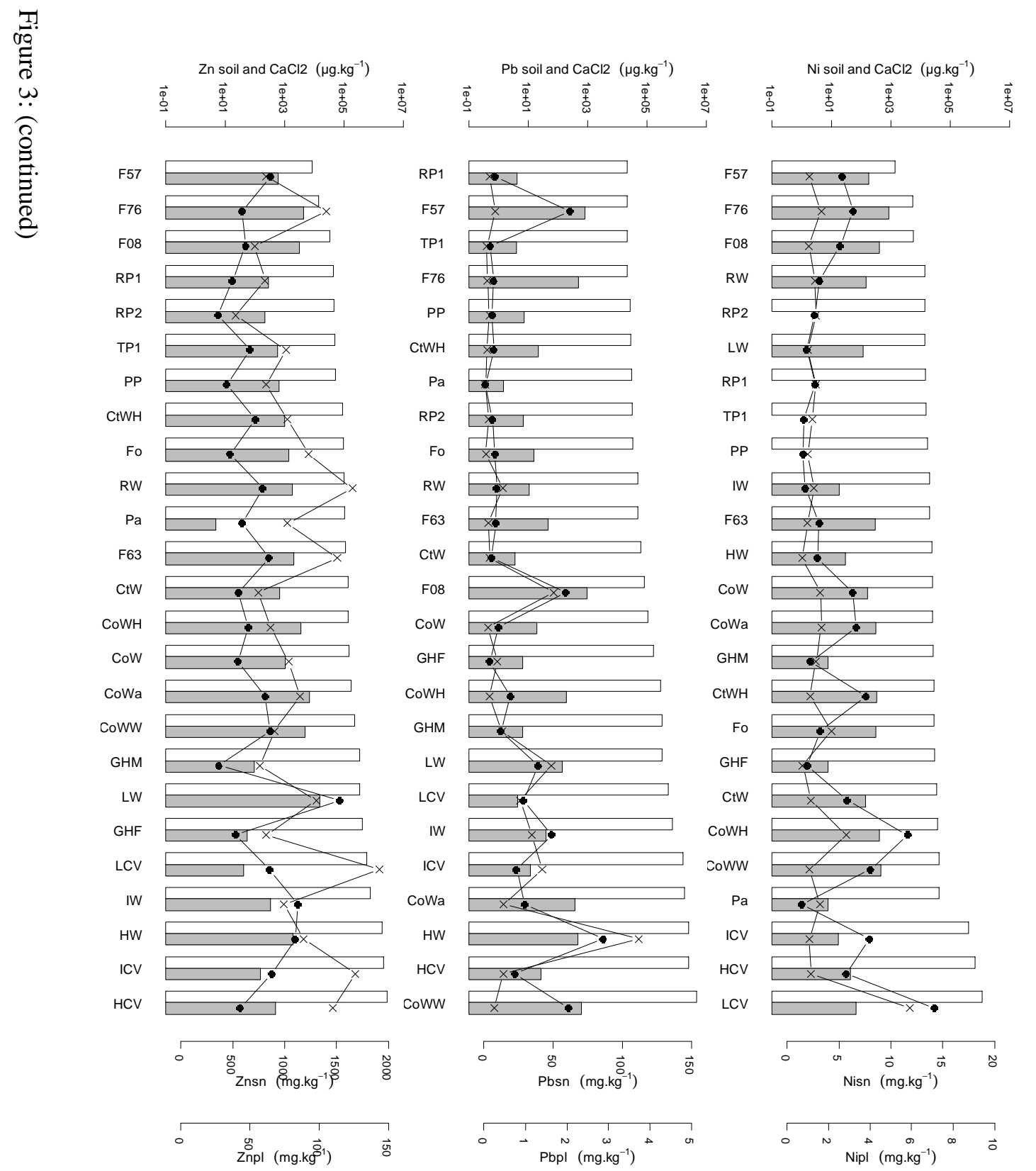




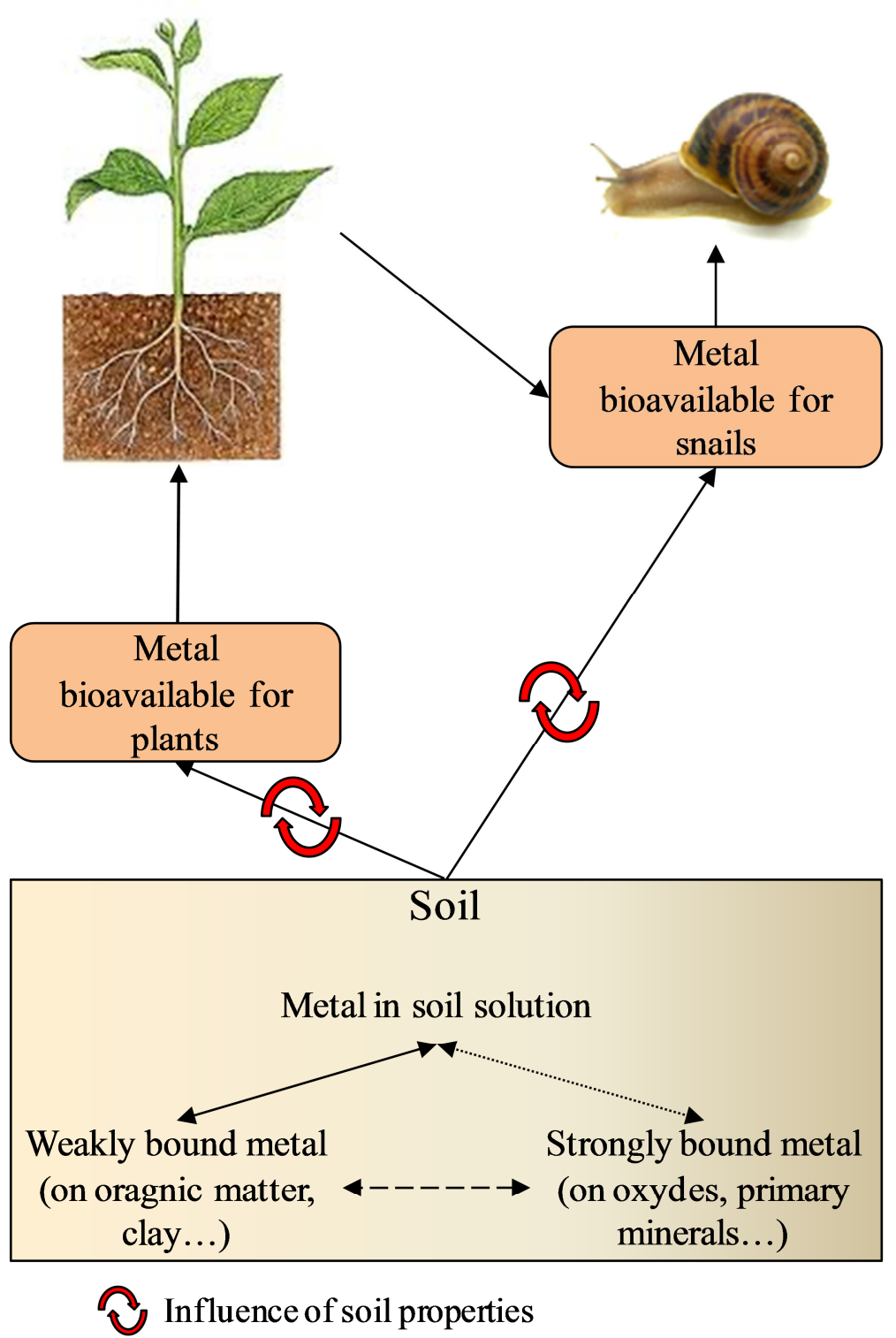

Figure 4: Synthetic schema of metal mobility and transfer from soil to organisms 


\section{TABLES}

Table 1: Main distribution parameters of TE contents $\left(\mathrm{mg} \mathrm{kg}^{-1} \mathrm{DW}\right)$ in plants, snails and soil (total and $\mathrm{CaCl}_{2}$ ) sampled on 25 plots from 7 sites

\begin{tabular}{ccccccccc}
\hline Metal & & $\mathrm{As}$ & $\mathrm{Cd}$ & $\mathrm{Cr}$ & $\mathrm{Cu}$ & $\mathrm{Ni}$ & $\mathrm{Pb}$ & $\mathrm{Zn}$ \\
\hline \multirow{4}{*}{ Plants } & Median & 0.519 & 0.233 & 0.644 & 9.20 & 1.75 & 0.395 & 50.4 \\
$(\mathrm{n}=125)$ & Min & 0.000 & 0.000 & 0.250 & 4.98 & 0.359 & 0.000 & 17.9 \\
& Max & 28.6 & 7.42 & 165 & 25.6 & 10.4 & 6.24 & 193 \\
& MAD & 0.609 & 0.233 & 0.264 & 2.78 & 1.22 & 0.374 & 22.8 \\
\hline \multirow{5}{*}{ Snails } & Median & 0.227 & 1.65 & 0.839 & 121 & 2.57 & 5.26 & 1072 \\
$(\mathrm{n}=150)$ & Min & 0.001 & 0.142 & 0.030 & 22.9 & 0.033 & 0.689 & 391 \\
& Max & 11.1 & 33.0 & 20.0 & 222 & 33.4 & 313 & 2422 \\
& MAD & 0.237 & 1.01 & 0.532 & 44.4 & 1.11 & 4.91 & 381 \\
\hline \multirow{3}{*}{ Soil } & Median & 30.35 & 0.612 & 56.8 & 22.8 & 25.7 & 78.9 & 138 \\
concentration & Min & 2.905 & 0.0165 & 6.55 & 1.73 & 1.4 & 21.045 & 8.61 \\
$($ Total, n=25) & Max & 3285 & 34.4 & 4345 & 1555 & 1180 & 4575 & 2830 \\
& MAD & 34.7 & 0.709 & 12.2 & 15.6 & 15.8 & 85.8 & 135 \\
\hline \multirow{2}{*}{ Soil } & Median & 26.925 & 33.6 & 5 & 76 & 150.5 & 19 & 689 \\
concentration & Min & 10 & 1.415 & 5 & 10.65 & 7.5 & 1.5 & 5 \\
$($ CaCl, n=25) & Max & 155050 & 578 & 41.9 & 681 & 847 & 924 & 15100 \\
& MAD & 25.1 & 43.1 & 0 & 61.8 & 212 & 22.2 & 940 \\
\hline
\end{tabular}


Table 2: Simple linear regression analysis and correlation study between TE contents in plants or in snails, and total TE in soil (extracted with $\left.\mathrm{HF}+\mathrm{HClO}_{4}\right) .(\mathrm{n}=25)$

\begin{tabular}{|c|c|c|c|c|}
\hline Element & Organism & Regression equation & $\mathbf{r}_{\text {adj }}^{2}$ & p-value \\
\hline \multirow{2}{*}{ As } & Plants & $\mathrm{As}_{\mathrm{pl}}=-0.081^{\mathrm{ns}}+0.170 \mathrm{As}_{\mathrm{tot}} * *$ & 0.27 & 0.005 \\
\hline & Snails & $\mathrm{As}_{\mathrm{sn}}=-0.108 *+0.153 \mathrm{As}_{\mathrm{tot}} * * *$ & 0.63 & $<0.001$ \\
\hline \multirow{2}{*}{$\mathrm{Cd}$} & Plants & $\mathrm{Cd}_{\mathrm{pl}}=\mathrm{ns}$ & -- & -- \\
\hline & Snails & $\mathrm{Cd}_{\mathrm{sn}}=0.324 * * *+0.395 \mathrm{Cd}_{\mathrm{tot}} * * *$ & 0.45 & $<0.001$ \\
\hline \multirow{2}{*}{$\mathrm{Cr}$} & Plants & $\mathrm{Cr}_{\mathrm{pl}}=-0.095^{5}+0.190 \mathrm{Cr}_{\mathrm{tot}} * *$ & 0.49 & $<0.001$ \\
\hline & Snails & $\mathrm{Cr}_{\mathrm{sn}}=0.019^{\mathrm{ns}}+0.135 \mathrm{Cr}_{\mathrm{tot}} * *$ & 0.23 & 0.009 \\
\hline \multirow{2}{*}{$\mathrm{Cu}$} & Plants & $\mathrm{Cu}_{\mathrm{pl}}=\mathrm{ns}$ & - & - \\
\hline & Snails & $\mathrm{Cu}_{\mathrm{sn}}=\mathrm{ns}$ & -- & -- \\
\hline \multirow{2}{*}{$\mathrm{Ni}$} & Plants & $\mathrm{Ni}_{\mathrm{pl}}=0.285^{* *}+0.140 \mathrm{Ni}_{\mathrm{tot}}{ }^{*}$ & 0.15 & 0.032 \\
\hline & Snails & $\mathrm{Ni}_{\mathrm{sn}}=0.417 * * *+0.106 \mathrm{Ni}_{\mathrm{tot}} *$ & 0.15 & 0.031 \\
\hline \multirow{2}{*}{$\mathrm{Pb}$} & Plants & $\mathrm{Pb}_{\mathrm{pl}}=-0.070^{\mathrm{ns}}+0.132 \mathrm{~Pb}_{\mathrm{tot}}{ }^{* *}$ & 0.35 & 0.001 \\
\hline & Snails & $\mathrm{Pb}_{\mathrm{sn}}=0.104^{\mathrm{ns}}+0.408 \mathrm{~Pb}_{\mathrm{tot}} * * *$ & 0.42 & $<0.001$ \\
\hline \multirow{2}{*}{$\mathrm{Zn}$} & Plants & $\mathrm{Zn}_{\mathrm{pl}}=\mathrm{ns}$ & - & - \\
\hline & Snails & $\mathrm{Zn}_{\mathrm{sn}}=2.821 * * *+0.091 \mathrm{Zn}_{\mathrm{tot}} *$ & 0.14 & 0.037 \\
\hline
\end{tabular}

Symbols for $p$-values in the regression equations are: ${ }^{\circ}<0.1, *<0.05, * *<0.01, * * *<0.001$ 
Table 3: Simple linear regression analysis and correlation study between TE contents in plants or in snails, and "available" TE in soil (extracted with $\left.0.01 \mathrm{M} \mathrm{CaCl}_{2}\right) .(\mathrm{n}=25)$

\begin{tabular}{|c|c|c|c|c|}
\hline Element & Organism & Regression equation & $\mathbf{r}^{2}{ }_{\text {adj }}$ & $p$-value \\
\hline \multirow{2}{*}{ As } & Plants & $\mathrm{As}_{\mathrm{pl}}=0.034^{\mathrm{ns}}+0.103 \mathrm{As}_{\mathrm{CaCl} 2}$ & 0.24 & 0.016 \\
\hline & Snails & $\mathrm{As}_{\mathrm{sn}}=-0.017^{\mathrm{ns}}+0.093 \mathrm{As}_{\mathrm{CaCl} 2} * * *$ & 0.60 & $<0.001$ \\
\hline \multirow{2}{*}{$\mathrm{Cd}$} & Plants & $\mathrm{Cd}_{\mathrm{pl}}=-0.097^{\mathrm{n}}+0.160 \mathrm{Cd}_{\mathrm{CaCl}}$ & 0.32 & 0.001 \\
\hline & Snails & $\mathrm{Cd}_{\mathrm{sn}}=0.178^{\mathrm{ns}}+0.201 \mathrm{Cd}_{\mathrm{CaCl}_{2}} *$ & 0.20 & 0.013 \\
\hline \multirow{2}{*}{$\mathrm{Cr}$} & Plants & $\mathrm{Cr}_{\mathrm{pl}}=\mathrm{ns}$ & -- & -- \\
\hline & Snails & $\mathrm{Cr}_{\mathrm{sn}}=\mathrm{ns}$ & -- & -- \\
\hline \multirow{2}{*}{$\mathrm{Cu}$} & Plants & $\mathrm{Cu}_{\mathrm{pl}}=\mathrm{ns}$ & -- & -- \\
\hline & Snails & $\mathrm{Cu}_{\mathrm{sn}}=\mathrm{ns}$ & -- & -- \\
\hline \multirow{2}{*}{$\mathrm{Ni}$} & Plants & $\mathrm{Ni}_{\mathrm{pl}}=0.220^{\circ}+0.153 \mathrm{Ni}_{\mathrm{CaCl} 2} *$ & 0.23 & 0.017 \\
\hline & Snails & $\mathrm{Ni}_{\mathrm{sn}}=\mathrm{ns}$ & -- & -- \\
\hline \multirow{2}{*}{$\mathrm{Pb}$} & Plants & $\mathrm{Pb}_{\mathrm{pl}}=-0.014^{\mathrm{s}}+0.149 \mathrm{~Pb}_{\mathrm{CaCl} 2} * * *$ & 0.54 & $<0.001$ \\
\hline & Snails & $\mathrm{Pb}_{\mathrm{sn}}=\mathrm{ns}$ & -- & -- \\
\hline \multirow{2}{*}{$\mathrm{Zn}$} & Plants & $\mathrm{Zn}_{\mathrm{pl}}=\mathrm{ns}$ & -- & -- \\
\hline & Snails & $\mathrm{Zn}_{\mathrm{sn}}=\mathrm{ns}$ & -- & -- \\
\hline
\end{tabular}

Symbols for $p$-values in the regression equations are: ${ }^{\circ}<0.1, *<0.05, * *<0.01, * * *<0.001$ 
Table 4: Multiple linear regression analysis and correlation study between TE content in plants or in snails, and the main soil parameters as independent variables. Selected soil parameter were $\mathrm{pH}$, cation exchange capacity (CEC), sum of exchangeable cations (SEC), organic carbon content $\left(\mathrm{C}_{\text {org }}\right)$, clay and silts contents and total soil concentration (extracted with $\left.\mathrm{HF}+\mathrm{HClO}_{4}\right)$ of each studied element. $(\mathrm{n}=$ 25)

\begin{tabular}{|c|c|c|c|c|}
\hline Element & Organism & Regression equation & $\mathbf{r}^{2}{ }_{\text {adj }}$ & p-value \\
\hline \multirow{2}{*}{ As } & Plants & $\mathrm{As}_{\mathrm{pl}}=-0.081^{\mathrm{ns}}+0.170 \mathrm{As}_{\mathrm{tot}} * *$ & 0.27 & 0.005 \\
\hline & Snails & $\mathrm{As}_{\mathrm{sn}}=-0.108 *+0.153 \mathrm{As}_{\mathrm{tot}} * * *$ & 0.63 & $<0.001$ \\
\hline \multirow{2}{*}{$\mathrm{Cd}$} & Plants & $\mathrm{Cd} \mathrm{pl}_{\mathrm{pl}}=\mathrm{ns}$ & -- & -- \\
\hline & Snails & $\mathrm{Cd}_{\mathrm{sn}}=0.750 * * *+0.403 \mathrm{Cd}_{\mathrm{tot}} * * *-0.271$ Corg $*$ & 0.55 & $<0.001$ \\
\hline \multirow{2}{*}{$\mathrm{Cr}$} & Plants & $\mathrm{Cr}_{\mathrm{pl}}=0.178^{\circ}+0.205 \mathrm{Cr}_{\mathrm{tot}}{ }^{*} *-0.277 \mathrm{SEC} * * *$ & 0.69 & $<0.001$ \\
\hline & Snails & $\mathrm{Cr}_{\mathrm{sn}}=0.464 * *+0.230 \mathrm{Cr}_{\mathrm{tot}} * * *-0.117 \mathrm{pH}^{* *}+0.153 \mathrm{CaCO}_{3} *$ & 0.45 & 0.001 \\
\hline \multirow{2}{*}{$\mathrm{Cu}$} & Plants & $\mathrm{Cu}_{\mathrm{pl}}=\mathrm{ns}$ & -- & -- \\
\hline & Snails & $\mathrm{Cu}_{\mathrm{sn}}=\mathrm{ns}$ & -- & -- \\
\hline \multirow{2}{*}{$\mathrm{Ni}$} & Plants & $\mathrm{Ni}_{\mathrm{pl}}=1.484^{* * *}+0.226 \mathrm{Ni}_{\mathrm{tot}}{ }^{* *}-0.089 \mathrm{pH}^{* * *}-0.310$ Silts $* *$ & 0.62 & $<0.001$ \\
\hline & Snails & $\mathrm{Ni}_{\mathrm{sn}}=0.641 * * *+0.128 \mathrm{Ni}_{\mathrm{tot}} * *-0.235 \mathrm{SEC} *$ & 0.27 & 0.012 \\
\hline \multirow{2}{*}{$\mathrm{Pb}$} & Plants & $\mathrm{Pb}_{\mathrm{pl}}=0.106^{\mathrm{ns}}+0.184 \mathrm{~Pb}_{\mathrm{tot}}{ }^{* * *}-0.046 \mathrm{pH}^{*}$ & 0.45 & $<0.001$ \\
\hline & Snails & $\mathrm{Pb}_{\mathrm{sn}}=0.104^{\mathrm{ns}}+0.408 \mathrm{~Pb}_{\mathrm{tot}} * * *$ & 0.42 & $<0.001$ \\
\hline \multirow{2}{*}{$\mathrm{Zn}$} & Plants & $\mathrm{Zn} \mathrm{n}_{\mathrm{pl}}=\mathrm{ns}$ & -- & -- \\
\hline & Snails & $\mathrm{Zn}_{\mathrm{sn}}=2.960 * * *+0.150 \mathrm{Zn}_{\mathrm{tot}} * *-0.245 \mathrm{SEC}$ & 0.24 & 0.02 \\
\hline
\end{tabular}

Symbols for $p$-values in the regression equations are: ${ }^{\circ}<0.1, *<0.05, * *<0.01, * * *<0.001$ 
Table 5: Regression analysis and correlation study between TE content in snails, and various sets of explanatory variables $(n=25)$. PC: plant TE content; STC: soil TE total content; SSP: selected soil properties ( $\mathrm{pH}, \mathrm{CEC}, \mathrm{SEC}, \mathrm{C}_{\mathrm{org}}$, clay and silts contents).

\begin{tabular}{|c|c|c|c|c|}
\hline Element & $\begin{array}{c}\text { Explanatory } \\
\text { variables }\end{array}$ & Regression equation & $\mathbf{r}_{\text {adi }}^{2}$ & p-value \\
\hline \multirow{3}{*}{ As } & $\mathrm{PC}$ & $\mathrm{As}_{\mathrm{sn}}=0.075^{*}+0.310 \mathrm{As}_{\mathrm{pl}} * *$ & 0.22 & 0.01 \\
\hline & $\mathrm{STC}+\mathrm{PC}$ & $\mathrm{As}_{\mathrm{sn}}=-0.108^{*}+0.153 \mathrm{As}_{\mathrm{tot}} * * *$ & 0.63 & $<0.001$ \\
\hline & $\mathrm{STC}+\mathrm{PC}+\mathrm{SSP}$ & $\mathrm{As}_{\mathrm{sn}}=-0.108 *+0.153 \mathrm{As}_{\mathrm{tot}} * * *$ & 0.63 & $<0.001$ \\
\hline \multirow{3}{*}{$\mathrm{Cd}$} & $\mathrm{PC}$ & $\mathrm{Cd}_{\mathrm{sn}}=0.365 * * * 0.838 \mathrm{Cd}_{\mathrm{pl}} * *$ & 0.27 & 0.004 \\
\hline & $\mathrm{STC}+\mathrm{PC}$ & $\mathrm{Cd}_{\mathrm{sn}}=0.272 * * *+0.324 \mathrm{Cd}_{\mathrm{tot}} * * *+0.530 \mathrm{Cd}_{\mathrm{pl}} *$ & 0.54 & $<0.001$ \\
\hline & $\mathrm{STC}+\mathrm{PC}+\mathrm{SSP}$ & $\mathrm{Cd}_{\mathrm{sn}}=0.660^{* * *}+0.339 \mathrm{Cd}_{\mathrm{tot}} * *+0.468 \mathrm{Cd}_{\mathrm{p}} *-0.241 \mathrm{C}_{\mathrm{org}} *$ & 0.62 & $<0.001$ \\
\hline \multirow{3}{*}{$\mathrm{Cr}$} & $\mathrm{PC}$ & $\mathrm{Cr}_{\mathrm{sn}}=0.146^{*}+0.496 \mathrm{Cr}_{\mathrm{pl}}{ }^{*}$ & 0.21 & 0.012 \\
\hline & $\mathrm{STC}+\mathrm{PC}$ & $\mathrm{Cr}_{\mathrm{sn}}=0.019^{\mathrm{ns}}+0.135 \mathrm{Cr}_{\mathrm{tot}} * *$ & 0.23 & 0.009 \\
\hline & $\mathrm{STC}+\mathrm{PC}+\mathrm{SSP}$ & $\mathrm{Cr}_{\mathrm{sn}}=0.464 * *+0.230 \mathrm{Cr}_{\mathrm{tot}} * * *-0.117 \mathrm{pH}^{* *}+0.153 \mathrm{CaCO}^{*} *$ & 0.45 & 0.001 \\
\hline \multirow{3}{*}{$\mathrm{Cu}$} & $\mathrm{PC}$ & $\mathrm{Cu}_{\mathrm{sn}}=\mathrm{ns}$ & -- & -- \\
\hline & $\mathrm{STC}+\mathrm{PC}$ & $\mathrm{Cu}_{\mathrm{sn}}=\mathrm{ns}$ & -- & -- \\
\hline & $\mathrm{STC}+\mathrm{PC}+\mathrm{SSP}$ & $\mathrm{Cu}_{\mathrm{sn}}=\mathrm{ns}$ & -- & -- \\
\hline \multirow{3}{*}{$\mathrm{Ni}$} & $\mathrm{PC}$ & $\mathrm{Ni}_{\mathrm{sn}}=0.376 * * *+0.402 \mathrm{Ni}_{\mathrm{pl}} * *$ & 0.25 & 0.006 \\
\hline & $\mathrm{STC}+\mathrm{PC}$ & $\mathrm{Ni}_{\mathrm{sn}}=0.376 * * *+0.402 \mathrm{Ni}_{\mathrm{pl}} * *$ & 0.25 & 0.006 \\
\hline & $\mathrm{STC}+\mathrm{PC}+\mathrm{SSP}$ & $\mathrm{Ni}_{\mathrm{sn}}=0.376 * * *+0.402 \mathrm{Ni}_{\mathrm{p}} * *$ & 0.25 & 0.006 \\
\hline \multirow{3}{*}{$\mathrm{Pb}$} & $\mathrm{PC}$ & $\mathrm{Pb}_{\mathrm{sn}}=0.519 * * *+2.171 \mathrm{~Pb}_{\mathrm{pl}} * * *$ & 0.56 & $<0.001$ \\
\hline & $\mathrm{STC}+\mathrm{PC}$ & $\mathrm{Pb}_{\mathrm{sn}}=0.519 * * *+2.171 \mathrm{~Pb}_{\mathrm{pl}} * * *$ & 0.56 & $<0.002$ \\
\hline & $\mathrm{STC}+\mathrm{PC}+\mathrm{SSP}$ & $\mathrm{Pb}_{\mathrm{sn}}=-0.333^{\mathrm{ns}}+2.085 \mathrm{~Pb}_{\mathrm{pp}} * *+0.139 \mathrm{pH}^{* * *}$ & 0.75 & $<0.001$ \\
\hline \multirow{3}{*}{$\mathrm{Zn}$} & $\mathrm{PC}$ & $\mathrm{Zn}_{\mathrm{sn}}=2.196^{* * *}+0.481 \mathrm{Zn}_{\mathrm{pl}} * *$ & 0.24 & 0.007 \\
\hline & $\mathrm{STC}+\mathrm{PC}$ & $\mathrm{Zn}_{\mathrm{sn}}=2.196 * * *+0.481 \mathrm{Zn}_{\mathrm{pl}} * *$ & 0.24 & 0.007 \\
\hline & $\mathrm{STC}+\mathrm{PC}+\mathrm{SSP}$ & $\mathrm{Zn}_{\mathrm{sn}}=2.196^{* * *}+0.481 \mathrm{Zn}_{\mathrm{pl}} * *$ & 0.24 & 0.007 \\
\hline
\end{tabular}

Symbols for $p$-values in the regression equations are: ${ }^{\circ}<0.1, *<0.05, * *<0.01, * * *<0.001$ 


\section{ASSOCIATED CONTENT : Supporting Information}

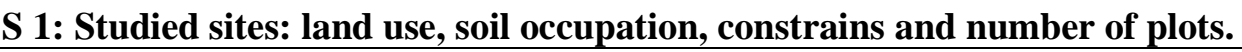

\begin{tabular}{|c|c|c|c|c|}
\hline Site & Land uses & Soil occupation & constraints & $\begin{array}{l}\text { No. of } \\
\text { plots }\end{array}$ \\
\hline $\begin{array}{l}\text { GISFI (French Scientific Interest Group - } \\
\text { Industrial wasteland) }\end{array}$ & Contaminated & Wastelands & Contamination in PAH & 2 \\
\hline Metaleurop & Contaminated & Arable, woodlands & $\begin{array}{l}\text { Multi-metals contamination }(\mathrm{Cd}, \\
\mathrm{Pb}, \mathrm{As})\end{array}$ & 7 \\
\hline Auzon & Contaminated & Arable, woodlands & Located contamination (As) & 6 \\
\hline SHSE (Slag Heap of Saint-Etienne) & Contaminated & Wastelands & $\begin{array}{l}\text { Metal diffused contmaination } \\
(\mathrm{Pb}, \mathrm{Cd}, \mathrm{Zn} \ldots)\end{array}$ & 3 \\
\hline Yvetot & Cultivated & Arable, pastures & Age of pastures & 6 \\
\hline $\begin{array}{l}\text { RENECOFOR (national Network of long-term } \\
\text { follow-up of the forest ecosystems) }\end{array}$ & Forest & Forest & Scots pines, spruces, fir tree & 4 \\
\hline $\begin{array}{l}\text { Andra (French noational radioactive waste } \\
\text { management agency) }\end{array}$ & Cultivated / Forest & Arable, forest & Different soil occupations & 2 \\
\hline
\end{tabular}


$\underline{\text { S 2: Main pedological characteristics of the } 25 \text { plots from the } 7 \text { sites studied (median values, } n=5 \text { ) }}$

\begin{tabular}{|c|c|c|c|c|c|c|c|c|c|c|}
\hline Site & Plot & $\begin{array}{c}\text { Clay } \\
\left(\mathrm{g} \mathrm{kg}^{-1}\right)\end{array}$ & $\begin{array}{l}\text { Silts } \\
\left(\mathrm{g} \mathrm{kg}^{-1}\right)\end{array}$ & $\begin{array}{l}\text { Sands } \\
\left(\mathrm{g} \mathrm{kg}^{-1}\right)\end{array}$ & $\begin{array}{c}\mathrm{C}_{\text {org }} \\
\left(\mathrm{g} \mathrm{kg}^{-1}\right)\end{array}$ & $\mathrm{pH}_{\mathrm{w}}$ & $\begin{array}{c}\mathrm{CEC} \\
\left(\mathrm{cmol} \mathrm{kg}^{-1}\right)\end{array}$ & $\begin{array}{c}\mathrm{SEC} \\
\mathrm{cmol}+\mathrm{kg}^{-1}\end{array}$ & $\begin{array}{c}\mathrm{CaCO}_{3} \\
\left(\mathrm{~g} \mathrm{~kg}^{-1}\right)\end{array}$ & $\begin{array}{c}\mathrm{N}_{\text {tot }} \\
\left(\mathrm{g} \mathrm{kg}^{-1}\right)\end{array}$ \\
\hline \multirow{2}{*}{ GISFI } & GHF & 143 & 225 & 611 & 121 & 8.3 & 15.0 & 17.8 & 249 & 2.99 \\
\hline & GHM & 94.0 & 172 & 736 & 210 & 8.3 & 11.0 & 14.6 & 137 & 4.17 \\
\hline \multirow{4}{*}{ Metaleurop } & HW & 298 & 601 & 101 & 48.3 & 8.0 & 29.3 & 31.4 & 50.6 & 3.40 \\
\hline & IW & 294 & 609 & 96.0 & 26.6 & 8.2 & 24.3 & 27.0 & 66.4 & 2.05 \\
\hline & LW & 203 & 283 & 517 & 31.8 & 6.5 & 17.2 & 17.1 & 0.500 & 2.27 \\
\hline & RW & 163 & 525 & 313 & 20.2 & 6.5 & 12.2 & 12.4 & 0.500 & 1.58 \\
\hline \multirow{6}{*}{ Auzon } & CoWW & 238 & 427 & 346 & 59.6 & 5.4 & 19.1 & 19.5 & 0.500 & 3.96 \\
\hline & $\mathrm{CoW}$ & 148 & 279 & 574 & 40.8 & 5.7 & 13.0 & 13.6 & 0.500 & 2.90 \\
\hline & CoWH & 89.5 & 167 & 757 & 44.2 & 5.2 & 11.0 & 11.5 & 0.500 & 3.33 \\
\hline & CoWa & 98.5 & 167 & 713 & 34.9 & 5.8 & 9.46 & 9.90 & 0.500 & 2.48 \\
\hline & $\mathrm{CtW}$ & 138 & 299 & 556 & 40.8 & 6.2 & 14.9 & 15.6 & 0.500 & 2.90 \\
\hline & $\mathrm{CtWH}$ & 148 & 225 & 628 & 26.2 & 5.1 & 8.90 & 9.29 & 0.500 & 2.03 \\
\hline \multirow{3}{*}{ SHSE } & $\mathrm{HCV}$ & 48.5 & 142 & 803 & 46.9 & 8.1 & 10.5 & 13.0 & 48.6 & 2.26 \\
\hline & ICV & 44.5 & 131 & 820 & 30.4 & 8.7 & 6.60 & 10.8 & 74.5 & 1.36 \\
\hline & $\mathrm{LCV}$ & 33.5 & 77.0 & 886 & 14.8 & 8.6 & 3.47 & 5.72 & 39.9 & 0.905 \\
\hline \multirow{4}{*}{ Yvetot } & RP1 & 140 & 665 & 196 & 11.1 & 5.6 & 5.43 & 6.40 & 0.500 & 1.14 \\
\hline & $\mathrm{RP} 2$ & 128 & 665 & 210 & 14.4 & 6.0 & 6.97 & 7.71 & 0.500 & 1.41 \\
\hline & TP1 & 149 & 652 & 202 & 18.9 & 5.5 & 7.25 & 8.09 & 0.500 & 1.83 \\
\hline & $\mathrm{PP}$ & 163 & 634 & 203 & 25.8 & 5.5 & 8.06 & 8.59 & 0.500 & 2.45 \\
\hline \multirow{4}{*}{ RENECOFOR } & F08 & 262 & 630 & 106 & 87.4 & 4.0 & 10.4 & 9.76 & 0.500 & 4.72 \\
\hline & F57 & 44.5 & 73.0 & 886 & 13.0 & 4.1 & 2.14 & 1.82 & 0.500 & 0.689 \\
\hline & F76 & 78.0 & 354 & 566 & 104 & 3.8 & 7.10 & 4.55 & 0.500 & 3.07 \\
\hline & F63 & 257 & 411 & 326 & 156 & 4.9 & 9.42 & 8.94 & 1.40 & 9.17 \\
\hline \multirow{2}{*}{ Andra } & Fo & 255 & 425 & 299 & 27.5 & 4.9 & 6.81 & 6.86 & 0.500 & 1.88 \\
\hline & $\mathrm{Pa}$ & 499 & 360 & 134 & 59.1 & 7.3 & 33.5 & 34.7 & 21.3 & 5.61 \\
\hline
\end{tabular}

SEC : sum of exchangeable cations (Al, $\mathrm{Ca}, \mathrm{Fe}, \mathrm{Mg}, \mathrm{Mn}, \mathrm{Na}$ ) 
S 3: Total $\left(\mathrm{HF}+\mathrm{HClO}_{4}\right.$ extraction $)$ and "available" $\left(\mathrm{CaCl}_{2}\right.$ extraction) TE contents at the 25 plots from the 7 sites studied (median values, $\left.\mathrm{n}=5\right)$. $\mathrm{NA}$ : no available data. italic values correspond to value below the detection limit

\begin{tabular}{|c|c|c|c|c|c|c|c|c|c|c|c|c|c|c|c|}
\hline \multirow[b]{2}{*}{ Site } & \multirow[b]{2}{*}{ Plot } & \multicolumn{7}{|c|}{ Total fraction $\left(\mathrm{mg} \mathrm{kg}^{-1}\right)$} & \multicolumn{7}{|c|}{ Available fraction $\left(\mu \mathrm{g} \mathrm{kg}^{-1}\right)$} \\
\hline & & {$[\mathrm{As}]_{\text {tot }}$} & {$[\mathrm{Cd}]_{\text {tot }}$} & {$[\mathrm{Cr}]_{\text {tot }}$} & {$[\mathrm{Cu}]_{\text {tot }}$} & {$[\mathrm{Ni}]_{\text {tot }}$} & {$[\mathrm{Pb}]_{\text {tot }}$} & {$[\mathrm{Zn}]_{\text {tot }}$} & {$[\mathrm{As}]_{\mathrm{CaCl} 2}$} & {$[\mathrm{Cd}]_{\mathrm{CaCl} 2}$} & {$[\mathrm{Cr}]_{\mathrm{CaCl} 2}$} & {$[\mathrm{Cu}]_{\mathrm{CaCl} 2}$} & {$[\mathrm{Ni}]_{\mathrm{CaCl} 2}$} & {$[\mathrm{~Pb}]_{\mathrm{CaCl} 2}$} & {$[\mathrm{Zn}]_{\mathrm{CaCl} 2}$} \\
\hline \multirow{2}{*}{ GISFI } & $\mathrm{GHF}$ & 32.8 & 0.499 & 57.1 & 30.3 & 29.0 & 165 & 408 & 15.5 & 6.12 & 5.00 & 84.6 & 7.50 & 6.39 & 55.1 \\
\hline & GHM & 58.5 & 1.23 & 172 & 45.3 & 26.9 & 309 & 323 & 23.4 & 7.56 & 5.00 & 143 & 7.50 & 6.52 & 94.8 \\
\hline \multirow{4}{*}{ Metaleurop } & HW & 39.3 & 34.4 & 48.6 & 68.4 & 23.5 & 2485 & 1885 & 34.2 & 415 & 5.00 & 234 & 30.4 & 465 & 1965 \\
\hline & IW & 30.9 & 13.3 & 50.3 & 27.6 & 19.8 & 731 & 745 & 10.0 & 79.3 & 5.00 & 93.3 & 18.3 & 39.1 & 340 \\
\hline & LW & 9.42 & 5.44 & 52.0 & 19.4 & 14.2 & 319 & 332 & 18.6 & 578 & 5.00 & 123 & 120 & 142 & 15100 \\
\hline & RW & 7.11 & 1.09 & 41.5 & 12.3 & 13.6 & 48.8 & 102 & 10.0 & 122 & 5.00 & 87.8 & 151 & 10.7 & 1835 \\
\hline \multirow{6}{*}{ Auzon } & CoWW & 3285 & 9.97 & 76.5 & 159 & 41.4 & 4575 & 225 & 155050 & 326 & 5.00 & 681 & 466 & 617 & 5020 \\
\hline & CoW & 339 & 0.722 & 57.9 & 22.9 & 25.7 & 104 & 148 & 1238 & 53.8 & 5.00 & 47.7 & 163 & 19.0 & 1080 \\
\hline & CoWH & 661 & 1.32 & 51.8 & 38.6 & 36.3 & 282 & 140 & 16895 & 120 & 5.00 & 126 & 418 & 194 & 3500 \\
\hline & CoWa & 1087 & 6.73 & 52.3 & 140 & 25.7 & 1834 & 173 & 10735 & 219 & 5.00 & 538 & 318 & 377 & 6660 \\
\hline & $\mathrm{CtW}$ & 123 & 0.612 & 67.3 & 27.7 & 35.0 & 60.1 & 138 & 233 & 33.6 & 5.00 & 76.0 & 136 & 3.54 & 689 \\
\hline & CtWH & 62.5 & 0.143 & 56.8 & 22.8 & 27.6 & 28.1 & 88.1 & 44.6 & 21.2 & 5.00 & 38.0 & 335 & 21.4 & 1006 \\
\hline \multirow{3}{*}{ SHSE } & $\mathrm{HCV}$ & 73.3 & 21.0 & 982 & 1555 & 685 & 2525 & 2830 & 10.0 & 17.6 & 11.6 & 653 & 43.5 & 26.5 & 492 \\
\hline & ICV & 54.8 & 9.37 & 1158 & 570 & 405 & 1616 & 2180 & 10.0 & 3.98 & 41.9 & 200 & 17.4 & 11.8 & 153 \\
\hline & $\mathrm{LCV}$ & 30.3 & 1.99 & 4345 & 525 & 1180 & 513 & 577 & 10.0 & 1.42 & 10.2 & 118 & 69.5 & 4.35 & 42.2 \\
\hline \multirow{4}{*}{ Yvetot } & RP1 & 6.93 & 0.236 & 66.3 & 10.3 & 14.6 & 21.0 & 42.7 & NA & 32.6 & NA & 34.3 & NA & 4.21 & 284 \\
\hline & RP2 & 6.76 & 0.243 & 49.0 & 14.4 & 13.9 & 30.6 & 47.0 & NA & 14.7 & NA & 46.1 & NA & 6.80 & 215 \\
\hline & TP1 & 8.52 & 0.205 & 51.2 & 13.7 & 15.6 & 21.4 & 48.4 & NA & 29.3 & NA & 61.4 & NA & 4.04 & 587 \\
\hline & $\mathrm{PP}$ & 9.48 & 0.198 & 53.8 & 13.4 & 16.9 & 26.3 & 51.5 & NA & 32.3 & NA & 51.2 & NA & 7.24 & 640 \\
\hline \multirow{4}{*}{ RENECOFOR } & F08 & 25.4 & 0.235 & 57.9 & 17.1 & 5.68 & 78.9 & 34.0 & 58.9 & 111 & 22.5 & 71.5 & 427 & 924 & 3175 \\
\hline & F57 & 3.83 & 0.017 & 6.55 & 1.73 & 1.40 & 21.1 & 8.61 & 30.5 & 11.7 & 5.00 & 32.5 & 179 & 826 & 604 \\
\hline & F76 & 2.91 & 0.063 & 17.7 & 3.48 & 5.53 & 21.9 & 13.5 & 46.4 & 41.5 & 5.00 & 24.0 & 847 & 485 & 4290 \\
\hline & F63 & 12.8 & 0.414 & 55.0 & 14.1 & 20.2 & 49.7 & 113 & NA & 64.0 & NA & 10.7 & 300 & 46.7 & 2035 \\
\hline \multirow{2}{*}{ Andra } & Fo & 16.6 & 0.328 & 71.1 & 9.57 & 27.9 & 32.5 & 93.3 & 10.0 & 62.7 & 5.00 & 15.9 & 316 & 16.0 & 1410 \\
\hline & $\mathrm{Pa}$ & 18.4 & 0.447 & 82.7 & 18.5 & 42.3 & 29.9 & 104 & 10.0 & 1.45 & 5.00 & 38.9 & 7.50 & 1.50 & 5.00 \\
\hline
\end{tabular}


S 3: Principal plant species on the studied plots.

\begin{tabular}{|c|c|c|}
\hline Site & Plot & Principal species on the plots \\
\hline \multirow{2}{*}{ GISFI } & GHF & $\begin{array}{l}\text { Achillea millefolium, Agrostis stolonifera, Arrhenatherum elatius, Artemisia vulgaris, Artemisia } \\
\text { campestris, Bromus hordeaceus, Bromus sterilis,Cerastium sp., Chenopodium album, Dactylis } \\
\text { glomerata, Echium ulgare, Epilobium parviflorum, Erigeron annuus, Euphorbia cyparissias, } \\
\text { Hypericum perforatum, Medicago lupulina, Melilotus albus, Malva moschata, Myosotis sp., } \\
\text { Oenothera biennis, Petrorhagia rolifera, Picris hieracioides, Plantago lanceolata, Prunus spinosa, } \\
\text { Robinia pseudoacacia, Rubus sp., Scrophularia sp., Sedum acre, Senecio jacobaea, Silene latifolia, } \\
\text { Tanacetum vulgare, Tragopogon ubius, Veronica chamaedrys, Vicia hirsuta, Vulpia ciliata }\end{array}$ \\
\hline & GHM & $\begin{array}{l}\text { Acer pseudoplatanus, Arrhenatherum elatius, Artemisia vulgaris, Astragalus glycyphyllos, Centaurea } \\
\text { jacea, Chenopodium album, Cirsium arvense, Clematis vitalba, Dactylis glomerata, Dipsacus } \\
\text { fullonum, Epilobium sp, Erigeron annuus, Euphorbia cyparissias, Geranium robertianum, Hypericum } \\
\text { perforatum, Medicago sativa, Oenothera biennis, Papaver rhoeas, Plantago lanceolata, Reseda lutea, } \\
\text { Rosa sp, Rubus sp, Rumex acetosella, Sanguisorba minor, Silene latifolia, Verbascum sp., Vulpia } \\
\text { ciliata }\end{array}$ \\
\hline \multirow{4}{*}{ Metaleurop } & HW & $\begin{array}{l}\text { Acer pseudoplatanus, Alnus glutinosa, Arrhenatherum elatius, Betula pubescens, Calystegia sepium, } \\
\text { Carex palustris, Cornus sanguinea, Crataegus monogyna, Elytrigia repens, Epilobium sp, Fraxinus } \\
\text { excelsior, Galium aparine, Glechoma hederacea, Myosotis arvensis, Quercus sp., Ranunculus repens, } \\
\text { Robinia pseudoacacia, Rubus sp, Salix sp., Sambucus nigra, Symphytum officinale, Urtica dioica }\end{array}$ \\
\hline & IW & $\begin{array}{l}\text { Acer pseudoplatanus, Arrhenatherum elatius, Cornus sanguinea, Crataegus monogyna, Dipsacus } \\
\text { fullonum, Elytrigia repens, Epilobium sp., Fragaria vesca, Galium aparine, Glechoma hederacea, } \\
\text { Myosotis arvensis, Populus sp., Ranunculus repens, Rubus sp, Sambucus nigra, Symphytum officinale, } \\
\text { Urtica dioica }\end{array}$ \\
\hline & LW & $\begin{array}{l}\text { Acer pseudoplatanus, Alnus glutinosa, Betula pubescens, Carpinus betulus, Castanea sativa, Corylus } \\
\text { avellana, Crataegus monogyna, Epilobium sp., Fraxinus excelsior, Galium aparine, Geranium } \\
\text { robertianum, Glechoma hederacea, Hedera helix, Ilex aquifolium, Lamium album, Milium effusum, } \\
\text { Myosotis arvensis, Parthenocissus inserta, Poa sp., Populus sp., Prunus avium, Quercus sp., Rubus } \\
\text { sp., Sambucus nigra, Stellaria holostea, Symphytum officinale, Urtica dioica }\end{array}$ \\
\hline & $\mathrm{RW}$ & $\begin{array}{l}\text { Acer pseudoplatanus, Clematis vitalba, Crataegus monogyna, Epilobium sp., Equisetum arvense, } \\
\text { Euonymus europaeus, Fraxinus excelsior, Galium aparine, Geranium robertianum, Glechoma } \\
\text { hederacea, Hedera helix, Lamium album, Myosotis arvensis, Populus sp.,Prunus avium, Quercus sp., } \\
\text { Ranunculus repens, Rubus sp., Salix sp., Urtica dioica, Vicia hirsuta }\end{array}$ \\
\hline \multirow{6}{*}{ Auzon } & CoWW & $\begin{array}{l}\text { Agrostis capillaris, Arum maculatum, Cornus sanguinea, Crataegus monogyna, Equisetum arvense, } \\
\text { Euphorbia dulcis subsp incompta, Hedera helix, Lonicera periclymenum, Quercus sp., Rubus sp., } \\
\text { Sambucus nigra, Urtica dioica, }\end{array}$ \\
\hline & CoW & $\begin{array}{l}\text { Apiaceae sp., Cornus sanguinea, Corylus avellana, Crataegus monogyna, Euonymus europaeus, } \\
\text { Hedera helix, Ligustrum vulgare, Lonicera periclymenum, Quercus sp., Rubus sp. }\end{array}$ \\
\hline & CoWH & $\begin{array}{l}\text { Agrostis capillaris, Alliaria petiolata, Apiaceae sp., Cirsium arvense, Cornus sanguinea, Crataegus } \\
\text { monogyna, Epilobium sp.1, Epilobium sp. 2, Equisetum arvense, Euonymus europaeus, Humulus } \\
\text { lupulus, Rubus sp., Urtica dioica, }\end{array}$ \\
\hline & CoWa & $\begin{array}{l}\text { Achillea millefolium, Agrostis capillaris, Apiaceae sp., Cytisus scoparius, Epilobium sp., Euphorbia } \\
\text { cyparissias, Galium aparine, Populus tremula, Quercus sp., Rubus sp., Rumex acetosella, Urtica } \\
\text { dioica, }\end{array}$ \\
\hline & $\mathrm{CtW}$ & $\begin{array}{l}\text { Alliaria petiolata, Anthriscus sylvestris, Arum maculatum, Chelidonium majus, Crataegus monogyna, } \\
\text { Euonymus europaeus, Galium aparine, Hedera helix, Lamium galeobdolon, Ligustrum vulgare, } \\
\text { Lunaria annua, Prunus spinosa, Sambucus nigra, Tillia platyphyllos, Urtica dioica, }\end{array}$ \\
\hline & CtWH & $\begin{array}{l}\text { Euonymus europaeus, Galium aparine, Glechoma hederacea, Hedera helix, Lamiaceae sp., Prunus } \\
\text { spinosa, Quercus sp., Rubus sp., Tillia platyphyllos }\end{array}$ \\
\hline \multirow{3}{*}{ SHSE } & $\mathrm{HCV}$ & $\begin{array}{l}\text { Ailanthus altissima, Calamintha nepeta, Clematis vitalba, Cornus sanguinea, Echium vulgare, } \\
\text { Euonymus europaeus, Hypericum perforatum, Lactuca serriola, Melilotus albus, Oenothera biennis, } \\
\text { Urtica dioica, Verbascum pulverulentum }\end{array}$ \\
\hline & ICV & $\begin{array}{l}\text { Ailanthus altissima, Calamintha nepeta, Fraxinus excelsior, Hypericum perforatum, Melilotus albus, } \\
\text { Oenothera biennis, Plantago sacbra subsp scabra, Populus nigra, Reseda lutea, Rosa sp., Sambucus } \\
\text { nigra, Urtica dioica, Verbascum pulverulentum }\end{array}$ \\
\hline & LCV & $\begin{array}{l}\text { Echium vulgare, Lactuca serriola, Melilotus albus, Hypericum perforatum, Oenothera biennis, } \\
\text { Plantago sacbra Moench subsp scabra, Populus nigra, Reseda lutea, Scrophularia canina, Verbascum } \\
\text { pulverulentum }\end{array}$ \\
\hline Yvetot & RP1 & $\begin{array}{l}\text { Carpinus betulus, Fumaria officinalis, Lamium purpureum, Lolium perenne, Poa annua, Rumex } \\
\text { acetosa, Stellaria media, Taraxacum sp., Trifolium repens, Urtica dioica, Veronica chamaedrys, }\end{array}$ \\
\hline
\end{tabular}




\begin{tabular}{|c|c|c|}
\hline & \multirow{3}{*}{$\begin{array}{l}\mathrm{RP} 2 \\
\mathrm{TP} 1\end{array}$} & \multirow{2}{*}{ Lolium perenne, Poa annua, Stellaria media, Trifolium repens, } \\
\hline & & \\
\hline & & $\begin{array}{l}\text { Cirsium sp., Holcus lanatus, Lamium album, Lamium purpureum, Lolium perenne, Ranunculus repens, } \\
\text { Rumex acetosa, Rumex acetosella, Stellaria holostea, Stellaria media, Taraxacum sp., Trifolium } \\
\text { repens, Urtica dioica }\end{array}$ \\
\hline & PP & $\begin{array}{l}\text { Cirsium sp., Crataegus monogyna, Fagus sylvatica, Lamium album, Lamium purpureum, Plantago } \\
\text { major, Ranunculus repens, Rumex acetosella, Stellaria holostea, Symphytum officinale, Taraxacum } \\
\text { sp., Urtica dioica }\end{array}$ \\
\hline \multirow{4}{*}{ RENECOFOR } & F08 & $\begin{array}{l}\text { Picea abies, Calluna vulgaris, Carex pilulifera, Deschampsia flexuosa, Galium mollugo, Rubus } \\
\text { fruticosus, Sorbus aucuparia, Vaccinium myrtillus }\end{array}$ \\
\hline & F57 & $\begin{array}{l}\text { Abies alba, Deschampsia flexuosa, Fagus sylvatica, Festuca altissima, Luzula luzuloides, Oxalis } \\
\text { acetosella, Picea abies, Rubus fruticosus, Rubus idaeus, Sorbus aucuparia, Vaccinium myrtillus }\end{array}$ \\
\hline & F76 & $\begin{array}{l}\text { Pinus sylvestris, Calluna vulgaris, Deschampsia flexuosa, Fagus sylvatica, Molinia caerulea, Rubus } \\
\text { fruticosus, Vaccinium myrtillus }\end{array}$ \\
\hline & F63 & $\begin{array}{l}\text { Abies alba, Agrostis capillaries, Campanula rotundifolia, Carex pilulifera, Cytisus scoparius, Digitalis } \\
\text { purpurea, Epilobium montanum, Fagus sylvatica, Gallium rotundifolium, Hypericum humifusum, } \\
\text { Picea abies, Rubus idaeus, Rumex acetosella }\end{array}$ \\
\hline \multirow[t]{2}{*}{ ANDRA } & Fo & $\begin{array}{l}\text { Fagus sylvatica, Galium aparine, Glechoma hederacea,, Hedera helix, Lamium album, Lamium } \\
\text { galeobdolon, Rubus fruticosus }\end{array}$ \\
\hline & $\mathrm{Pa}$ & Lolium perenne, Ranunculus repens, Rumex acetosella, Taraxacum sp., Trifolium repens \\
\hline
\end{tabular}

